\section{Pertenencia y exclusión social en Bariloche en clave devocional (1907-2017)}

\author{
Membership and social exclusion in Bariloche \\ in a devotional key (1907-2017)
}

\author{
Barelli, Ana Inés* \\ Nicoletti, María Andrea ${ }^{*}$
}

\section{Resumen}

Este trabajo se propone analizar acciones de pertenencia y lógicas de exclusión social en San Carlos de Bariloche a partir de la primera advocación mariana elegida en el poblado: la Inmaculada Concepción (1907) desde sus procesiones y peregrinaciones en la ciudad.

CONICET/Instituto en Diversidad Cultural y procesos de Cambio (IIDyPCa)/Universidad Nacional de Rio Negro. inebarelli@hotmail.com

** CONICET/Instituto en Diversidad Cultural y procesos de Cambio (IIDyPCa)/Universidad Nacional de Rio Negro. mariaanadreanicoletti@gmail.com
La Inmaculada fue la Patrona de la primera capilla fundada por los Salesianos y la elite empresarial chileno europea pertenecientes al catolicismo orgánico. Las procesiones de la Inmaculada "fundadora", marcaron territorialidad a partir de 1925 en el centro de la ciudad y de cara al lago. Hacia la década de 1990 la comunidad de migrantes paraguayos trasladó a Bariloche una Inmaculada bajo la advocación de Caacupé. Esta Inmaculada "migrante" de fuerte impronta popular, disputó a través de sus peregrinaciones un espacio diferenciado, periférico y alejado del circuito turístico de la Inmaculada "fundadora", resignificando a través de sus prácticas religiosas la "paraguayidad" de esta comunidad en el lejano sur.

Palabras clave: Bariloche, Inmaculada. Caacupé, peregrinaciones, identidades sociales.

\begin{abstract}
This work intends to analyze actions of belonging and logics of social exclusion in San Carlos de Bariloche from the first Marian invocation in the village: The Immaculate Conception (1907) from their processions and pilgrimages in the city. The Immaculate was the Patroness of the first chapel founded by the Salesians and the business Chilean-European elite belonging to organic Catholicism. The processions of the "founding" Immaculate marked territoriality from 1925 at the center of the city and the lake. Towards the 1990s, the Paraguayan migrant community moved to Bariloche an Immaculate under the patronage of Caacupé. Such "Migrant Immaculate" of strong popular imprint disputed through her pilgrimages a differentiated space, peripheral and far from the touristic circuit of
\end{abstract}


the "founding" Immaculate, resignifying through religious practices the "paraguayidad" of this community in the distant south.

Keywords: Bariloche, Immaculate, Caacupé, pilgrimages, social identities.

\section{Introducción}

La devoción a la Virgen María constituye una de las prácticas centrales del catolicismo. Esta devoción surge inmersa en profundos debates cuyos puntos cruciales fueron: la declaración del dogma de la Inmaculada Concepción el 8 de diciembre de 1854, por el que se proclamaba a la Virgen concebida sin pecado y la Asunción de María en cuerpo y alma en 1950. Esta devoción, a diferencia de otras, tiene la virtud de adaptarse y asumir la singularidad de los diversos lugares en donde se la venera. Esta ductilidad, que se manifiesta en sus diferentes advocaciones, le imprime características tanto territoriales como poblacionales, lo que a decir de Ameigeiras (2014) proporciona "cercanía y proximidad y por lo tanto la superación de distanciamientos con un Dios lejano o con una jerarquía demasiada separada de los sentires y problemas de las mujeres y hombre del pueblo" (Ameigeiras 2014: 175). En América la devoción mariana se instaló y expandió con la conquista sustentada en la evangelización, pero profundamente arraigada en las tramas culturales preexistentes a la colonización. Para los pueblos originarios americanos la presencia de las deidades femeninas como la Pachamama, la madre tierra, poseían un profundo significado donde la imagen de la mujer está estrechamente vinculada a la fecundidad humana y de la tierra. Este sincretismo se materializó en imágenes planas y de bulto, que adquirieron formas, gestos y colores relacionadas con las particularidades de las comunidades de fieles y sus localidades, que le otorgaban una singularidad especial (Ameigeiras 2014). De esta manera la devoción a la Virgen María se constituye como un símbolo poseedor de densidad significativa que le posibilita articularse con facilidad con otras tramas religiosas donde lo femenino posee relevancia y donde, siguiendo a Fogelman "los aspectos cambiantes y las diferentes coordenadas del culto mariano nos enfrenta a la complejidad del accionar de los actores sociales con sus conflictos (...) y a un proceso de conquista, acumulación y/o resistencia del poder que se encuentra distribuido irregularmente en una especie de retícula social compleja" (2006:6). Así, por ejemplo no solo surgen advocaciones sincréticas, "pensadas por la Iglesia para ser apropiadas por los indígenas y los grupos mestizos para lograr su incorporación a la fe", (Mora Rivera y Odone Correa 2011:72) sino que también refieren a producciones colectivas de lo religioso, atravesadas por factores de clase, etnicidad y nacionalidad (Wright, 2009; Martín, 1997) que, en algunos casos, son movilizadas por sus creyentes a otras latitudes y sometidas a procesos de resignificación cultual y reconfiguración espacial (Giorgis 2004; Sassone 2009; Barelli, 2013).

La ciudad de San Carlos de Bariloche, ubicada en las zonas próximas al río Limay y al Lago Nahuel Huapi, se encuentra al oeste de la provincia de Río Negro, sobre los andes patagónicos y en lo que se denomina regionalmente como la Norpatagonia. Constituye desde sus orígenes, a fines del siglo XIX, una ciudad conformada por diferentes desplazamientos poblacionales, siendo especialmente importante la presencia 
chilena $^{1}$ y la migración interna provenientes de distintas provincias del país. En un segundo plano se registra el ingreso de migrantes europeos como italianos, españoles y alemanes, en los periodos de postguerra, que constituyen núcleos particulares a través de sus asociaciones, y actualmente, una creciente migración latinoamericana proveniente de países como Bolivia y Paraguay, entre otros. En trabajos anteriores ${ }^{2}$ hemos advertido que en la ciudad se entrecruzan diferentes advocaciones marianas que se identifican con los procesos de construcción identitaria de la sociedad, a la que caracterizamos como aluvional y con asentamiento fragmentado. La desigualdad social que se retroalimenta con los mecanismos de exclusión, ha generado una ciudad con fuertes niveles de fragmentación espacial, impuesta no solo por el desarrollo urbano y por las políticas públicas de vivienda y plantificación sino también por los mismos migrantes que "se agruparon y reforzaron su identidad migrante en el destino" (Matossian 2012: 281). En función de ello, en esta oportunidad nos interesa analizar cuáles han sido las acciones de pertenencia y las lógicas de inclusión o exclusión social de dos advocaciones ${ }^{3}$ marianas que, si bien comparten el mismo título mariano ${ }^{4}$, son dos

En su mayoría chilenos de origen alemán provenientes de la zona de Llanquihue (Méndez 2007; Matossian 2012)

2 Ver Nicoletti y Barelli $(2012,2014,2015)$

3 Las advocaciones son las formas de nombrar a la Virgen en relación a sus fenómenos taumatúrgicos (Presentación, Anunciación, etc) o bien a sus apariciones, sus dones, sus atributos y los lugares geográficos y santuarios, o sea lugares santos desde una mirada hagiotoponimica (López Santos, 1969:579-214), que generan cofradías y patrocinios.

4 "Los títulos marianos" indican un aspecto del Misterio de Cristo, así como la realidad eclesial” (Esquerda Bifet, 1998: 460): María Madre (filiación de Cristo), María Inmaculada (sin pecado original ni personal) y María Asunta (victoria de Cristo sobre la muerte)
Inmaculadas, operan cultual y socialmente de forma diferente en el espacio local.

La Inmaculada Concepción, ha sido la primera advocación mariana elegida como patrona del poblado (1907).Esta advocación particular, dogma de la Iglesia desde 1854, fue promovida desde la élite empresarial chileno europea, en función de la afirmación del catolicismo orgánico en un territorio de frontera. Su demarcación territorial, a través de la peregrinación, impulsada por esta misma élite conservadora en la década de 1930, refuerza el imaginario de la Suiza Argentina ${ }^{5}$, de cara al lago vinculada al proyecto del nacionalismo católico. En este contexto, la Inmaculada y su parroquia permanecen como símbolo de los orígenes católicos del poblado vinculados a la élite urbana, operando como matriz identitaria de la ciudad, distribuyendo poder y creando territorialidad. Esta impronta de la Inmaculada "fundadora" en los años 1990, fue puesta en tensión a partir del traslado de la comunidad 6 paraguaya de otra Inmaculada que tiene como advocación a Caacupé. Esta Inmaculada "migrante" no solo se resignifica cultualmente y canaliza una identidad paraguaya o una "paraguayidad" en el lugar de destino,

"Suiza argentina" como la tierra de "pioneros europeos" constituye uno de los imaginarios en el discurso hegemónico sobre Bariloche. En el proceso histórico denominado por Dimitriu como de turistificación, la "Suiza argentina" evocaba a la inmigración europea en consonancia al racismo decimonónico y de "aristocratización". Navarro Floria y Vebjsberg, suman a esta calificación el acompañamiento del proceso de urbanización de la colonia agrícola pastoril que pone en valor la tierra para el mercado inmobiliario, mediante operaciones políticas y sociales a favor de esta "gentry". Elite de poder que influyó en la construcción identitaria de la ciudad.

6 En consonancia con la idea de Brow (1990), abordamos el concepto de comunidad como un grupo de personas que comparten un sentido de pertenencia desde el conocimiento y el afecto. De acuerdo a este autor, observamos en este colectivo un proceso de "comunalización" donde los migrantes construyen pautas de pertenencias y consolidan una "comunidad" en el destino. 
sino que también interpela a la Inmaculada "fundadora" a partir de su vínculo estrecho con los sectores populares y desde la demarcación territorial de un circuito religioso diferencial, alejado del lago y más próximo a la periferia de la ciudad.

En función de ello, nos proponemos analizar a la Virgen Inmaculada desde su advocación y desde su particular práctica cultual: las peregrinaciones en Bariloche. Desde su advocación analizaremos la identificación de este singular título y su elección como símbolo de la primera presencia católica en el poblado con la construcción de la capilla. En contraposición incorporaremos a este análisis el traslado de una Inmaculada particular: la Virgen de los paraguayos en la advocación de Caacupé en la década del ' 90 . Desde la peregrinación observaremos como la Inmaculada "fundadora" y la "migrante" (Caacupé), operan configurando identidades fragmentadas y construyendo espacios sagrados diferenciados.

La metodología que utilizaremos en esta oportunidad es de tipo cualitativa a través del análisis de fuentes escritas (crónicas de la parroquia Inmaculada Concepción y Archivo del Obispado de la Diócesis de San Carlos de Bariloche); orales (entrevistas a sacerdotes y obispo, a referentes migrantes devotos y a devotos no migrantes) y audio-visuales (fotografías de imágenes marianas de bulto, peregrinaciones y misas obtenidas en el trabajo de campo realizado).

\section{La Inmaculada Concepción en Bariloche. Origen, títulos y advocaciones}

\subsection{La primera capilla en el poblado (1907)}

Cuando Bariloche era una colonia agrícola pastoril $^{7}$, poblada por chilenos del sur $y$ gerenciada por comerciantes, también chilenos de origen alemán, que poblaban el lago Llanquihue (1895), la Congregación Salesiana estableció su primer nodo educativo misionero ${ }^{8}$ en Junín de los Andes (1892), desde donde proyectaba "abrir al menos otro centro de misión en $\mathrm{S}$. Carlos de Bariloche y destinar dos parejas de misioneros tanto a Junín como a S. Carlos y entonces se podría hacer sino todo, al menos gran parte de cuanto tenemos que hacer" (ACS F066 Visita extraordinaria Pietro Ricaldone, 1909). Como se había logrado en Junín, el proyecto salesiano buscaba fundar una capilla para atender desde allí a la población rural, mayoritariamente indígena, y construir un Colegio católico para la educación de la niñez de ambos sexos" (ASP Crónicas de la Casa San Carlos de Bariloche, 22/1/1907:f. $31)$, en un espacio en el que ya había educación protestante y se imponía la educación laica y

El gobierno nacional fundó en 1902 por decreto la Colonia Agrícola Ganadera del Nahuel Huapi.

8 Los Salesianos son una congregación de sacerdotes y laicos fundada por Juan Bosco en 1859 en Turín, Italia y aprobada en 1869 por la Santa Sede. La Congregación fue denominada por el mismo Don Bosco como Pía Sociedad bajo la advocación de San Francisco de Sales y sus miembros se denominaron comúnmente como "Salesianos de Don Bosco" (sdb). En 1871 María Dominga Mazzarello fue la cofundadora de la rama femenina, denominada "Hijas de María Auxiliadora" (fma). Los Salesianos e Hijas de María Auxiliadora desde 1880 instalaron escuelas y un circuito de misiones volantes y reducciones en la Patagonia que se articularon con las del territorio chileno. El padre Milanesio, que cruzó numerosas veces la cordillera, trajo desde Chile a las Hijas de María Auxiliadora y fundó su centro de misión en Junín de los Andes en 1892, vinculándose con Bariloche entre 1901 y 1907, a través del misionero salesiano Zacarías Genghini. 
"argentinizadora" del Estado con la ley 1420 (Teobaldo y Nicoletti 2007).

La iniciativa de dotar a Bariloche de una primera capilla católica la tuvieron los "vecinos caracterizados" del poblado, que constituyeron la "aristocracia local" ya que tenían el poder económico y los vínculos políticos que les permitían "defender sus intereses" (Teobaldo y García 1997: 265. "Estos grupos dominantes, fundamentalmente comerciantes, invertían en tierras y ganado, generaban proyectos productivos y disputaban el poder político local-Consejos Municipales y Juzgados de paz-, mediante la integración de agrupaciones vecinales, proto-partidos o -avanzado el siglo $X X$ - filiales de partidos con estructura nacional. A su vez participaban activamente en el espacio social creando clubes, asociaciones, impulsando escuelas y prohijando o fundando periódicos y diarios vinculados con la defensa de sus intereses" (Ruffini 2017:35). En este caso, los miembros de la comisión pro templo participaba mayoritariamente en torno a la empresa Chile-Argentina. "Empresa de capitales transnacionales (que) se estableció como el principal antecedente económico y político en la Norpatagonia argentino chilena. Asentada en un espacio de bajo control burocrático por parte de los estados con soberanía, la empresa estableció marcos y normas propias que le permitieron ejercer verdadera soberanía y negociar políticamente con los Estados involucrados, cual fuera un tercer sujeto de derecho" (Méndez y Muñoz 2013:176).

La alianza entre la élite local y la Iglesia se materializó en la presencia física de la capilla que alentó y secundó el superior de la Congregación en la región, Esteban Pagliere: por los nobles y cristianos anhelos de dotar a Bariloche de una Iglesia a cuya sombra se reunirán sus hijos en los días clásicos de la Religión y de la Patria, evocando el recuerdo de sus padres que aún a costa de sacrificios edificaron una morada de Dios. Ruégole, pues, quiera presentar mis sinceras felicitaciones a las beneméritas comisiones de damas y caballeros por esa empresa tan cristiana como civilizadora y principalmente al señor Presidente titular don Luis Horn por el generoso propósito de adelantar a la comisión 9000 \$ a nombre de la "Compañía Chile Argentina. (ASPCCSCB3/10/1906 f.27).

La comisión estaba presidida por el gobernador del Territorio, que también gestionaba fondos en el Congreso de la Nación para la capilla. Quien revisaba el presupuesto era nada menos que Primo Capraro, empresario y principal accionista de la empresa Chile Argentina (Méndez y Muñoz 2013). Pero fue Luis Horn el apoderado de la empresa Hube y Achelis de Puerto Montt, quien propuso "adelantar los fondos necesarios para la construcción de la Iglesia con la condición de que venga un padre de la Congregación Salesiana a dirigir los trabajos y atender los demás negocios" (APS Cl 25/7/1906: f. 26). Esta condición ocasionó una negociación "ad hoc" entre Capraro y Horn y también con la Congregación salesiana, qué si bien ofreció la supervisión de Genghini y Milanesio por turnos, no prometió un misionero fijo en la capilla.

Acto seguido y a pedido del Sr. Presidente D Luis Horn se procedió hacer constatar en la presente acta que el mencionado Señor Presidente con el fin de no perjudicar a la comisión, generosamente ofreció al Sr. Capraro abonarle todos los gastos que puede haber tenido con la condición que le devuelvan el contrato. A esta proposición contestó Capraro, aceptar la propuesta del Sr. 
Horn (...) que haya conformidad unánime en la comisión y al mismo tiempo que indemnización que el este en conformidad con el importe de la indemnización. También se hace constar en la presenta acta y a pedido del Sr. Vocal Benito Crespo que el dinero que la Compañía Chile Argentina adelanta para la construcción de Iglesia le sería devuelto con las limosnas, suscriciones (sic) y etc que el padre cura podrá recoger" (APS CI 25/7/ 1906, f.26).

Fue Genghini quien tramitó con el departamento de Tierras y Colonias de Buenos Aires el solar elegido (A manz 36) (APS, CCl, 20/1/1907, f.31 y Telegrama 26/12/06). Aunque Tierras y Colonias sólo concedió un terreno dentro de la manzana (APS, Cl, 18/1/1907 f. 31). Esta alianza institucional se concretó como hemos observado en las Crónicas, entre la élite y los Salesianos, pero tuvo diferencias notables hacia 1913 cuando dos vecinos inmigrantes comerciantes de la compañía comercial ganadera "Chile Argentina", con residencia en Bariloche que seguían la ruta de los lagos en su actividad comercial, se quejaban ante la Santa Sede por la falta de atención de la Congregación objetando que "esta iglesia ha servido solo para realizar las ceremonias religiosas cuando un sacerdote católico pasa por aquí a lo largo de uno de sus viajes (...) (Archivo Propaganda Fide NS vol 581. Doc. 245: Carta del Señor Don A. Nichell. Compañía Inglesa. Pilcañyeu- Rio Negro al Colegio Propaganda Fide, Bariloche, 16 de junio de 1913) ${ }^{9}$.Aunque Tierras y Colonias sólo concedió un terreno dentro de la manzana (APS CI 18/1/1907: f. 31).

La condición de Luis Horn y la insistencia de la comisión ante el Pro Vicario Pagliere de la presencia salesiana en Bariloche respondió a

\footnotetext{
Traducción del francés de Florencia Galante (IIDyPCa)
}

proyectos diferentes. Mientras que, para los salesianos Bariloche seguía siendo un punto de misión del nodo de Junín, para los comerciantes era un centro estratégico que buscaban afianzar y dominar y que corrían peligro por esos años en pleno declive de la empresa Chile Argentina, por la guerra mundial. "En el marco de las disputas limítrofes ${ }^{10}$ con Chile, instante en el que la prensa porteña acusó directamente a los empresarios de la Hube y Achelis de agentes chilenos y llamó al Estado Nacional a intervenir" (Méndez y Múñoz 2013:176). Justamente al siguiente año de inicio de la guerra y poco antes que finalizara, los Salesianos decidieron transformar esa "posta misionera" de San Carlos de Bariloche, en centro definitivo y casa permanente con la colaboración de los estancieros: "El padre envío varias cartas a estancieros del campo pidiendo ayuda para pagar los gastos contraídos en la edificación de la casa de Misión y ensanche de la capilla de San Carlos de Bariloche" (ASP, CCSCB, Libreta de Crónicas de la Casa de Misión de San Carlos de Bariloche, 8/7/1915).

Los pobladores de Bariloche, especialmente los "vecinos caracterizados" que habían construido la capilla con fondos de la Empresa, lograron hacia 1914 que aquella capilla que se había fundado como una posta misionera fuera un centro católico permanente a cargo de los Salesianos.

Un año después en 1914 la capilla construida por la Chile Argentina quedó a cargo de un salesiano: el Padre Marchiori:

10 Nos referimos a los "Pactos de Mayo" (1902) por los que Argentina se compromete a no meterse en cuestiones de política exterior de la República de Chile. El marco general de estos pactos fue para la solución de diferendos limítrofes en aquellos casos en los que no hubiese acuerdo a través de una negociación directa. Otro de los convenios limitaba los armamentos para detener la carrera armamentista entre Chile y la Argentina. 
"En fin, el pueblo en general se manifestó muy contento por la llegada y permanencia del cura en San Carlos de Bariloche (...). Durante el día el cura visitó varias familias anunciando su permanencia definitiva y agradeciendo las que habían enviado útiles para la casa y cocina (ASP CCSCB: Libreta de Crónicas de la Casa de Misión de San Carlos de Bariloche, 19 y 23 de marzo de 1915).

Esta "reinauguración" continuó con la contribución de "la Compañía Chilena Argentina en primera línea, después José García, Ermino Carro, Rubén Fernández, Cornelio, la señora de Juan Riveiro, la Señora de Alanís, varios turcos a los que le dieron efusivamente las gracias" (ASP, CCSCB, Libreta de Crónicas de la Casa de Misión de San Carlos de Bariloche, 28/11/1915). El nodo salesiano en Bariloche se constituyó definitivamente en 1915 con la llegada del P. Julio Mauro quien junto con el hermano coadjutor José Caranta, que era enfermero y zapatero (ASP CCSCB: Libreta de Crónicas de la Casa de Misión de San Carlos de Bariloche, 10/11/ 1915), construyeron el primer Hospital, que fue creciendo, atendido por el Hermano Caranta (Nicoletti 2017 Informe STAN).

EI P. Julio Mauro, destinado de forma permanente en la localidad en 1916, ratificó la elección del patronazgo mariano elegido por la comisión de 1907: La Inmaculada Concepción.

Nota importante habiendo entremanos los registros de la comisión pro templo de Bariloche el día 24 de enero de 1916.Lego: Que el 16 de junio de 1907 se juntó la comisión para elegir el patrono de la iglesia bajo lapresidencia del señor Luis Morchio, la comisión o ambas comisiones a unanimidad de votos resultó la Inmaculada Concepción de María y por segundo patrono
San Antonio de Padua (ASP CCSCB: Libreta de Crónicas de la Casa de Misión de San Carlos de Bariloche, 24/1/ 1916).

Sin embargo, las libretas de Crónicas de la Misión de San Carlos de Bariloche que comienza el P. Marchiori en 1915 y continúa el P. Mauro en 1916, se inician con un sello peculiar: la iconografía del primer Santo Patrono, San Carlos Borromeo, elegido junto a la Virgen Auxiliadora por los Salesianos en la colocación de la piedra fundamental de la capilla el 30 de enero de 1907. Esta marca simbólica de la Congregación formó parte del cruce de poder político, religioso y económico que tuvo como epicentro la capilla y que veremos a continuación en el siguiente apartado.

\subsection{La elección de la primera advocación mariana en Bariloche: "La Inmaculada fundadora"11 (1907)}

La segunda materialización de esta alianza la constituyó la elección del patronazgo de la capilla en la Inmaculada Concepción. La imagen religiosa resulta, sin duda, una manifestación visual determinante. Su contenido real y profundamentesimbólicologra un impacto social inmediato. Lo que nos interesa, "no es el estatuto de verdad de los enunciados religiosos, sino la relación que mantienen estos enunciados con el tipo de sociedad o de cultura que dan cuenta de los mismos. De esta forma se han convertido en síntomas, signos de algo distinto de lo que queremos decir" (Julià, 1974:139). No debemos olvidar tampoco como, particularmente en la Iglesia católica, las imágenes religiosas y su devoción están asociadas a la norma,

Término que utilizamos para referirnos a la Virgen Inmaculada, la primera devoción elegida en los inicios del poblado de Bariloche. 
a un discurso educativo homogeneizador y disciplinador. Las dos advocaciones marianas asociadas a la construcción de la capilla fueron la Virgen Auxiliadora, en el momento de la colocación y bendición de la piedra fundamental y la Inmaculada, tras la inauguración oficial y bendición del Templo. En el primer caso, fue el salesiano Genghini, gestor del templo, quien la bendijo bajo esta particular advocación salesiana, eligiendo como el santo patrono que la acompañaba, a San Carlos Borromeo, probablemente por el nombre completo del poblado, además de ser Borromeo el santo de la contrarreforma católica tras el surgimiento del protestantismo durante el siglo XVI.

El reverendo presbítero Zacarías Genghini de la Pía Sociedad Salesiana y misionero de esta región, legítimamente autorizado bendijo y colocó la piedra fundamental de esta iglesia católica bajo la advocación de Nuestra Señora Auxiliadora y San Carlos Borromeo (ASP CCSCB30/01/1907:36).

Pero, previamente al acto de bendición oficial con las autoridades el 19 de abril de 1908, "se procedió en la elección según la forma ordinaria, esto es, previa convocación de los vecinos del pueblo que fueran gustoso proclamar a su Santo Patrono" (ASP CCSCB 25/6/1907:24). Esta decisión certificada por el salesiano Genghini fue exactamente una asamblea general de los vecinos del pueblo, sino la reunión de los "miembros de ambas comisiones constructoras pro templo", las que suscriben posteriormente el acta:

Declarada abierta la sesión, fue designado el secretario para que recogiera de cada uno de los presentes su voto verbal, resultando electo por unanimidad de votos la Inmaculada
Concepción de María, cuya fiesta se celebra el ocho de diciembre y como segundo patrono San Antonio de Padua (ASP, Crónicas de la Inmaculada. (ASP CCSCB16/6/1907:35).

El salesiano Domingo Milanesio frente a las comisiones y las autoridades "bendijo solemnemente la capilla de esta localidad bajo la Advocación de Nuestra Señora La Purísima Concepción (ASPCCSCB: 19/4/1908).

Las advocaciones de la Virgen María son tomadas como un dispositivo que nos permite construir un territorio devocional en clave identitaria y resignificar espacios reales y simbólicos como construcciones territoriales dinámicas. Estos espacios están diferenciados por su inclusividad o exclusividad social que, en cada contexto histórico pueden territorializar la advocación, marcando fronteras simbólicas dónde las ideologías se apropian de los iconos y los rituales y nos permiten resignificarlas localmente. Ambas advocaciones, la Auxiliadora y la Inmaculada, más allá de ser la misma Virgen, están íntimamente relacionadas en cuanto a sus significantes dentro de la Iglesia Católica12. Su singularidad y su elección hace referencia al proceso de "comunalización" (Brown 1990) que cada grupo percibe como propio construido desde sus relaciones sociales, culturales e históricas.

La Auxiliadora, si bien es uno de los títulos más antiguos de la cristiandad ${ }^{13}$, fue resignificada por

12 Según el estudio de Farioli sobre la Virgen Auxiliadora de Don Bosco, el fundador de los Salesianos eligió hacia 1863 una imagen de Santa María de la Victoria, unida a la defensa de la Iglesia y del Papa contra los herejes con la corona de doce estrellas que representa a la Inmaculada para la iconografía de la Auxiliadora de los Salesianos

13 Desde el siglo IV después de Cristo, las comunidades cristianas y distintas figuras destacadas de la Iglesia entre los siglo IV y VI DC en la cristiandad de Oriente, dieron a la Virgen el nombre de 
Don Bosco en Turín como Patrona y forjadora de la Obra salesiana, quién eligió para su iconografía atributos de la Inmaculada (Stella 1981). Don Bosco además acompañó especialmente al Papa Pío IX ${ }^{14}$ en la proclamación del dogma ${ }^{15}$ en el siglo XIX. La Inmaculada y la Auxiliadora son devociones asociadas a los "tiempos difíciles": durante la unidad de Italia entre 1860 y $1862{ }^{16} \mathrm{y}$ en la Argentina entre 1879 y $1884^{17}$ (Nicoletti 2012). De amplia difusión en ambos continentes, incluso en las luchas por la independencia en el continente americano, la Inmaculada ha tenido una notable influencia que se evidencia en símbolos nacionales (Temporelli, 2008:43). Su simbología ensambla perfectamente con la situación de la Patagonia como "tierra de infieles", "capaz de enfrentarse con la fuerza

"Auxiliadora" con los siguientes sentidos: "La que trae auxilios venidos del cielo", la de "Auxilio potentísimo" de los seguidores de Cristo, "Auxiliadora de los que sufren", "Auxiliadora de los que rezan, exterminio de los malos espíritus y ayuda de débiles"; "Auxiliadora de los que gobiernan"; María es Auxiliadora de los que están en la tierra y la alegría de los que ya están en el cielo"; "Auxiliadora para conseguir la salvación. Auxiliadora para evitar los peligros", "Auxiliadora en la hora de la muerte", "Auxiliadora de los pobres", "Auxiliadora contra los enemigos de la fe y de los ejércitos para que defiendan la patria".

14 El Papa Pío IX fue un Papa muy cercano a la Congregación Salesiana. En su gobierno llevó adelante distintos actos referidos a la defensa doctrinal y la preservación de los Estados Pontificios amenazados por la unificación italiana.

15 El dogma de la Inmaculada Concepción, por la Bula Ineffabilis Deus de Pio IX en 1854, sostiene que la Virgen María, nació sin pecado original.

16 Nos referimos al momento en el que el Conde de Cavour en 1852 proclama el estado laico y la libertad religiosa. La Ley Siccardi sobre la inmunidad eclesiástica (1850). La ley Rattazzi que suprimió órdenes religiosas en 1854 y la inestabilidad en la que se encontraba el Papa en el Vaticano que lo llevaron en distintas oportunidades al exilio.

17 Nos referimos al período entre 1880 y 1884 en el que gobernaba Julio Roca, que previamente había realizado como ministro de Guerra la campaña de conquista de la Patagonia en 1879. Roca expulsó al Nuncio apostólico, se negó a reconocer el Vicariato y la Prefectura apostólica creadas por el vaticano en la Patagonia (1883) y promovió un conjunto de leyes denominadas laicas de educación común y matrimonio civil. bruta destructora del mal, llegando a inspirar la lucha ante las fuerzas de la opresión" (Temporelli, 2008:143). Porello, posteriormente la Virgen Inmaculada fue venerada por Don Bosco como Auxilium Christianorum o "ayuda de los cristianos" (Stella 1981:160), resignificada como Patrona de su Congregación y de las misiones a la Patagonia ${ }^{18}$.

La presencia protestante inicial en la pequeña aldea barilochense, también reforzó la elección de la Inmaculada cuyo dogma resultó un punto de inflexión con el protestantismo y otros credos cristianos ya que en "el misterio de la Inmaculada Concepción (...) (donde) María aparece venerada en solitario, sin su hijo (Temporelli 2008:141).

La imagen donada por los vecinos del poblado de Bariloche, que procesionó a principios del siglo $X X$, fue "la efigie de Nuestra Señora de Lourdes, la Inmaculada" (ASP CCSCB8/12/1928: f.40). Una imagen que reafirma el dogma por su aparición en la Gruta de Lourdes en $1858^{19}$. De hecho, la preocupación por la difusión del dogma formó parte de los ritos locales y particulares: (...) estando la Iglesia repletísima exponiendo verdades con tanta claridad sobre el dogma de la Inmaculada Concepción que cautivaba la admiración de los creyentes" (ASP CCSCB 8/12/ 1930: f.63).

\footnotetext{
Desde el siglo IV después de Cristo, las comunidades cristianas dieron a la Virgen el nombre de "Auxiliadora". El título orientado al Auxilio en los tiempos difíciles fue el que asoció Don Bosco en relación al contexto político y religioso de su época. Don Bosco eligió hacia 1863 para su representación iconográfica una imagen de Santa María de la Victoria, unida a la defensa de la Iglesia y del Papa contra los herejes con la corona de doce estrellas que representa a la Inmaculada (Farioli 2002). Su iconografía fue elaborada por Don Bosco y pintada en el retablo del Santuario de María Auxiliadora de Valdocco (Turín) por Tommaso Lorenzone. (Farioli, 2002).
}

19 El mensaje de la Virgen en la Gruta es: "Yo soy la Inmaculada Concepción". 
Figura 1: Fotos Capilla Inmaculada Concepción.

Archivo de la Parroquia de la Inmaculada Concepción y Archivo visual patagónico (1908)

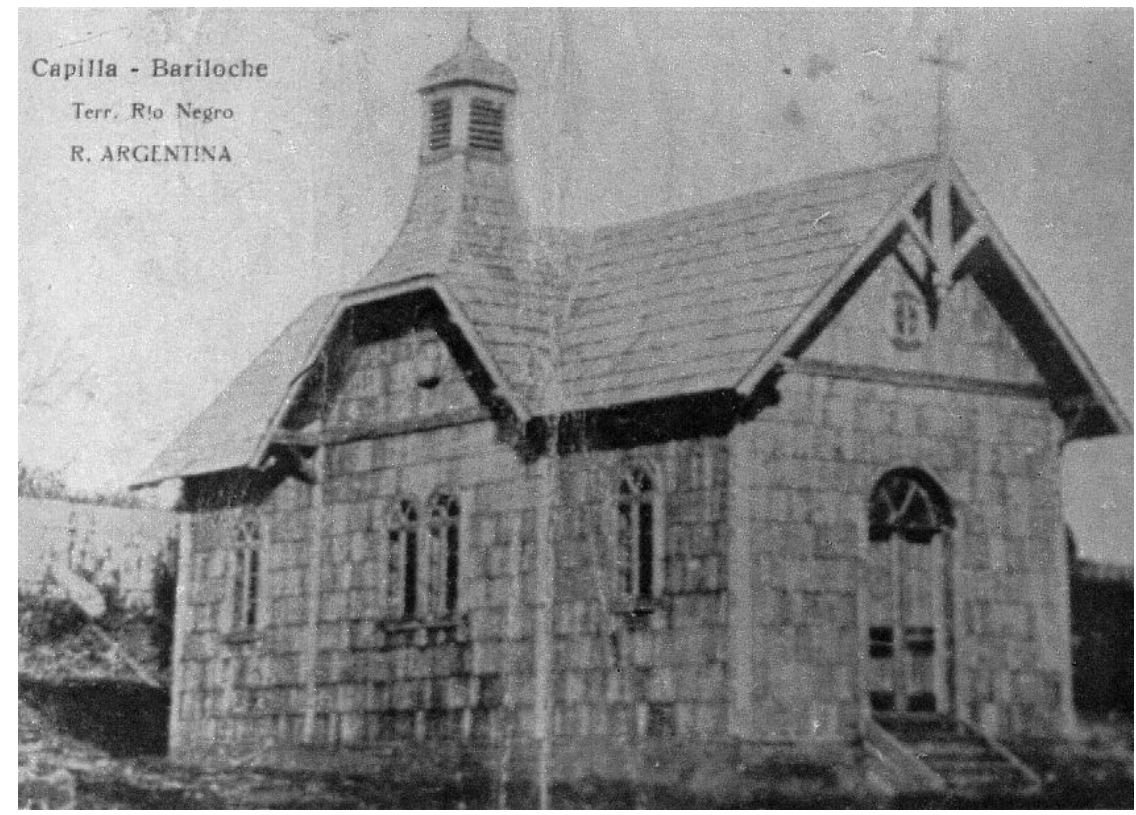

Para las comisiones de Damas y Caballeros Pro Templo que conformaban la élite local, como ya hemos analizado, la Inmaculada resulta un símbolo adecuado para el desarrollo del catolicismo orgánico ${ }^{20}$ que se afirma en la siguiente etapa en la localidad e identificaba a estos grupos (Mallimaci 1992): los colores de su vestido, la definición de su título mediante un dogma, su festividad declarada feriado el 8 de diciembre, son algunos de los símbolos que la posicionan como una Virgen patrona en tierras de frontera. Además, esta Virgen remitía a la primera misión jesuita transcordillerana en tiempo coloniales (Nicoletti 2014), aquella imagen que le envió el Virrey del Perú, Conde de
Lemus al misionero Nicolás Mascardi: "una bella imagen de la Purísima Virgen María, para que la colocase en la primera capilla que levantase entre los Poyas (...) tomándola por patrona de su misión (Enrich 1891: 742). Las crónicas de la capilla del primer poblado de Bariloche aluden a "la Inmaculada que desde 1793 se venera en la zona como consta del libro 'Viajes de Fray Menéndez', como he tenido oportunidad de leerlo. No es precisamente la misma imagen sino que en un libro se dice como un virrey del Perú había enviado a las misiones del lago Nahuel Huapi una estatua de la Inmaculada Concepción" (ASP CCSCB, 8/12/1928: f. 40)²1.

$21 \quad$ El estudio de Fonck publicado en 1900, sobre los viajes que hizo el franciscano Fray Francisco Menéndez entre 1791 y 1793 en búsqueda la Misión del Nahuel Huapi, cita al cronista jesuita F. Enrich, que también menciona el envío del Virrey de "medallas, 
La elección de la Inmaculada por sobre la Auxiliadora de los Salesianos nos permite advertir "la influencia del imaginario (...) sobre las identidades individuales y colectivas, así como su estrecha relación con la legitimación del poder religioso como factor político" (Fogelman 2013: 10).

Como conformadora de identidad, "su dinámica de transformación histórica genera o fortalece identidades sociales en construcción, que en muchos casos por su extensión y masificación resultan fuente de identidades nacionales" (Mallimacci 1992). Esta construcción se visibiliza en la unanimidad del voto por una comisión entre los que se encontraban germano chilenos, italianos, españoles y libaneses entre otros. Es decir, esta advocación posibilitó un cierto consenso en la opción por un título mariano que va más allá de las advocaciones nacionales para la conformación de una aristocracia local, caracterizada en las fuentes parroquiales como "familias de arraigo" (ASP CCSCB 8 de diciembre de 1930: 63).

Sin embargo, en los años 1990 esta "identidad barilochense" que se muestra homogenizante y totalizadora, se puso en tensión con el traslado de otra Inmaculada que "rompe" e interpela ese molde conservador y elitista que durante varias décadas se sostuvo con la "Inmaculada fundadora".

estampas y una imájen de la Virjen Purísima para la capilla de Nahuelhuapi".
Figura 2: API. Carpeta de Fotos de Peregrinaciones y Procesiones. Peregrinación de la Inmaculada en San Carlos de Bariloche 1981. Imagen de la Virgen de Lourdes que se veneraba en la Parroquia.

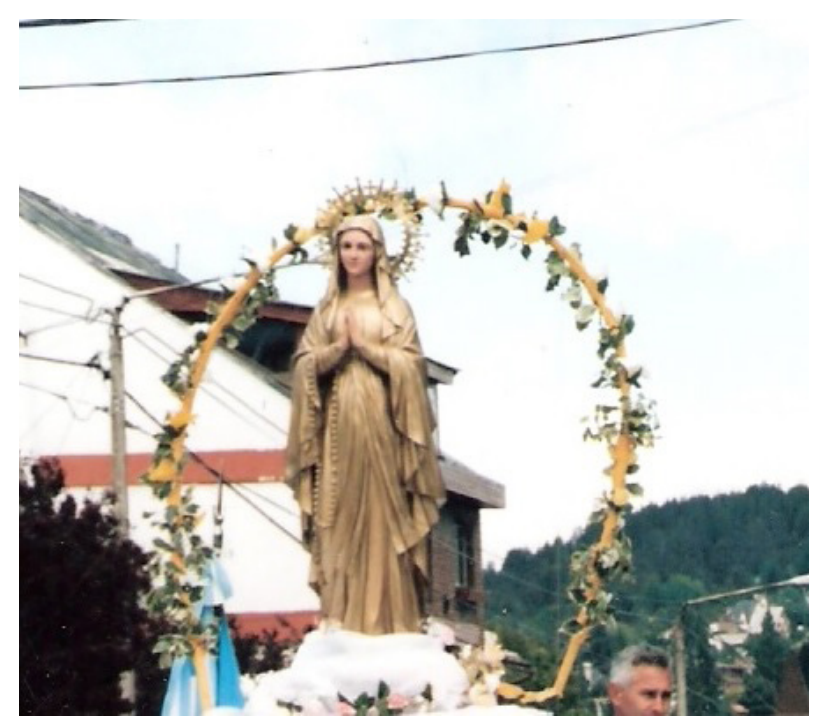

\subsection{La Inmaculada "migrante"22: la Virgen de Caacupé (1993)}

La Inmaculada "migrante" bajo la advocación Nuestra Señora de los Milagros de Caacupé23 se trasladó a principios de los años 1990 a San Carlos de Bariloche como una devoción con adscripción nacional y con un fuerte contenido social que se instaló en los sectores más pobres y desde ese lugar interpeló al espacio local.

\footnotetext{
Término que elegimos para referirnos a la Virgen de Caacupé devoción trasladada por los migrantes paraguayos a la ciudad de Bariloche en el año 1993.

23 Schenone (2008) señala que Nuestra Señora de los Milagros de Caacupé es una Purísima cuya composición en la vestimenta difiere de la Inmaculada Concepción. El manto azul celeste está recogido debajo del brazo izquierdo como si flotara y une sus manos sobre el pecho. Posee una larga cabellera. La imagen se apoya sobre una esfera con el símbolo por excelencia de la Inmaculada: la serpiente y la media luna.
} 
Desde el aspecto iconográfico, Nuestra Señora de Caacupé, es una Inmaculada Concepción de origen español ${ }^{24}$ conocida como la "Patrona de Paraguay".

Figura 3. Imagen de la "Nuestra Señora de los Milagros de Virgen de Caacupé"

Santuario de Caacupé a 55 km de Asunción, Paraguay.

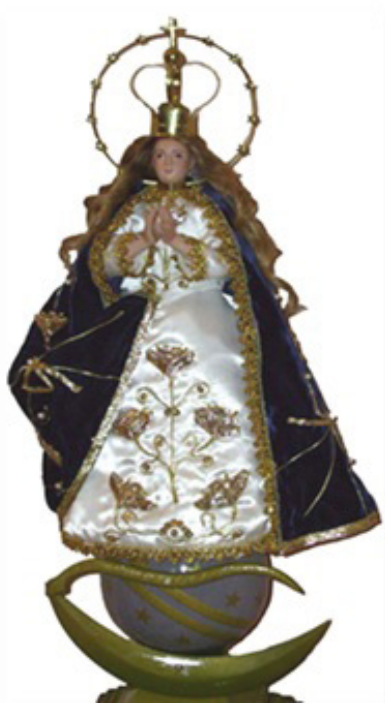

Fuente:http://alparaguay.blogspot.com.ar/2010/10/ virgen-de-caacupe-patrona-de-paraguay.html
El origen de la advocación de Caacupé ${ }^{25}$, se entrecruza con leyendas y relatos populares que son transmitidos de boca en boca en Asunción, ciudad capital de Paraguay. La Virgen de Caacupé la talló un artista nativo guaraní en el siglo XVII, luego de haber presenciado un "milagro". Según la leyenda el artista nativo vivía en un pueblo llamado Tobatí de Paraguay evangelizado por los franciscanos. Un día el artista fue a buscar materiales para sus tallas y se vio acorralado por un grupo de mbayanes ${ }^{26}$ que querían matarlo. El artista guaraní asustado se escondió detrás de un árbol y le rezó a la Virgen de la Inmaculada Concepción prometiendo que si se salvaba de sus perseguidores le tallaría una imagen del mismo tronco que lo había protegido. Los mbayanes pasaron delante del árbol donde se encontraba y no lo vieron (Reingold, 2000). Es a partir de este acontecimiento milagroso que la advocación pasa a conocerse con el nombre de Caacupé que significa en guaraní "detrás del monte" en alusión al lugar en donde se erigió el primer oratorio en su nombre. Tiempo después, debido a una serie de milagros que se produjeron en los lugares donde se entronizaba la imagen, le agregaron al nombre de Caacupé la denominación de "Nuestra Señora de los Milagros"27. Caacupé, de esta manera, se construye con una identidad local que le otorga singularidad y características propias.

${ }^{25}$ Caacupé en guaraní significa detrás del monte. Lugar elegido por un nativo para construir su primer oratorio.

26 Tribu nativa de la región.

27 Con el correr de los años, y después de varias situaciones donde la Virgen se salva "milagrosamente" de inundaciones, tormentas y guerras, en 1770 se construye el primer Santuario de Caacupé y en ese mismo año Carlos Morphy funda la ciudad de Caacupé. Santuario que se ve afectado por la guerra de la Triple Alianza y queda destrozado. En 1883 se construye un nuevo santuario que se termina en 1885 y es el que se conserva actualmente. En Reingold, Paula Verónica, Nuestra Señora de los Milagros de Caacupé, Editorial Santa María, Buenos Aires, 2000. 
Para el caso de Bariloche, como ya hemos advertido, la devoción de Caacupé la incorporan los migrantes paraguayos, que desde la década del 70' constituyen en la ciudad un flujo constante y significativo junto con la migración boliviana y la histórica migración chilena. Esta migración responde, al igual que en otros momentos y en otras zonas de la Argentina, a la situación histórica de pobreza que padece hace décadas Paraguay y a las ofertas laborales que ofrece la ciudad en materia de construcción. Según los datos ofrecidos por la Delegación Nacional de Migraciones de la ciudad, la migración paraguaya creció exponencialmente ${ }^{28}$ durante los últimos años.

Es en este contexto de migración que identificamos el ingreso de la primera imagen de Caacupé a la ciudad, la cual vino de la mano de una iniciativa en 1993 de Juan de Dios González, migrante oriundo de Asunción que llegó a Bariloche a fines de 1970. Antes de abocarnos al desarrollo del culto en la ciudad, resulta significativo describir brevemente la importancia de Juan de Dios como referente en la ciudad y la situación que lleva a que se decida trasladar la devoción e iniciar los festejos en el espacio local.

28 La migración paraguaya, en los últimos años, pasó de un total de 95 personas nacidas en Paraguay, registradas en el Censo 2001, a un total de 335 en el Censo 2010. Estos datos se pueden ampliar con información actual ofrecida por la DNM correspondiente al periodo 2010-2015. En este periodo se registraron un total de 5090 radicaciones resueltas, es decir un $43,2 \%$ de aumento del total de población extranjera del censo 2010. De estas radicaciones. De estas radicaciones un $72 \%$ corresponden a migrantes pertenecientes al Mercosur. Dentro de este grupo resulta significativo mencionar, por un lado, el crecimiento que vienen teniendo ya desde algunas décadas las migraciones provenientes de Bolivia y Paraguay las cuales han duplicado y hasta triplicado sus ingresos como también la recuperación del primer lugar en los ingresos de nuestros vecinos trasandinos. En este sentido podemos observar que del total de radicaciones del 2010 al 2015 , el $34,4 \%$ corresponden a migrantes chilenos, el $21,7 \%$ a paraguayos y el $19,4 \%$ a bolivianos representando el $70 \%$ de los ingresos (Barelli, 2018).
Juan de Dios, constituye una de las personas fundamentales para comprender el traslado y puesta en funcionamiento del culto en la ciudad. En 1982 organizó a la colectividad fundando la agrupación (A.R.P.A) ${ }^{29}$ y a partir de ese momento no sólo ocupó el rol de presidente por varios años sino que también pasó a ser el principal referente ${ }^{30}$ de la comunidad paraguaya de la ciudad. Este liderazgo se reforzó en el ámbito laboral, debido a su desempeño como contratista de obra, rubro de importante desarrollo en Bariloche, en el que trabajan la mayoría de los migrantes paraguayos (Barelli, 2015).

Durante los primeros años de A.R.P.A, la agrupación se dedicó a generar actividades que posibilitaran la "visibilización" 31 de los migrantes en la ciudad como la participación en la Fiesta de la Nieve y el intento de instalar en la ciudad la Fiesta de las Colectividades Latinoamericanas. Debido a los fracasos reiterados en los eventos públicos por falta de participación de la ciudadanía, diferencias entre sus miembros y

29 Asociación de Residentes Paraguayos que se funda, según su carta de fundación, con el objetivo de "formar a la colectividad" "unirse, recordar, difundir los aspectos de la cultura paraguaya" y "bregar por la efectiva unión y fraternal convivencia de la familia paraguaya y ser hogar y amparo común de todos los paraguayos residentes y transeúntes en la ciudad". Reseña histórica de ARPA presentada en el Folleto por los festejos de los "200 años de Paraguay". Bariloche, 2011

30 Juan de Dios, como hemos mencionado en otras publicaciones, "se constituyó como referente de la comunidad migrante en base a relaciones que generaron y generan gratitudes y lealtades que le dan prestigio dentro de la comunidad y, en consecuencia, profundizaron ese liderazgo personal" (Barelli, 2015: 187).

31 En artículos anteriores, hemos visto que San Carlos de Bariloche estuvo estrechamente asociado a la migración europea construyendo el imaginario de la ciudad como la "Suiza Argentina" o la tierra de "pioneros europeos", imágenes recurrentes en el discurso dominante local. "Estas representaciones sociales se forjaron en diferentes momentos históricos y sedimentaron imaginarios que ocultaron la relevancia que tuvieron y tienen los migrantes latinoamericanos en el entramado social, económico y cultural de la ciudad" (Barelli, 2015:179). 
dificultades económicas, la agrupación decide iniciar el culto de la Virgen de Caacupé para buscar otro vínculo que vuelva a unir a A.R.P.A y que genere otra relación con la sociedad local (Barelli, 2015).

La primera imagen de bulto que Juan de Dios traslada a la ciudad, corresponde a una réplica de aproximadamente de $30 \mathrm{~cm}$. Esta imagen, para poder utilizarla en las peregrinaciones, la entronizaron en un pequeño altar portátil de madera que facilitó el traslado durante el culto ${ }^{32}$. También, se la hizo bendecir por el Sacerdote Juvenal Currulef $^{33}$ de la Parroquia Virgen Misionera ${ }^{34}$ y se la cubrió con una ornamentación con la adscripción nacional de los migrantes. En el año 1994 la devoción incorpora nuevos sentidos, donde los devotos resignifican el culto, incorporando rituales, discursos, festividades dando sentido a lo que ellos denominan como paraguayidad, termino habitualmente utilizado por los migrantes para referirse a ese conjunto de elementos identitarios (simbólicos, discursivos, lingüísticos y materiales), que constituyen lo que los migrantes denominan como la "cultura paraguaya" $^{35}$ (Barelli 2013).

La incorporación y organización del culto por parte A.R.P.A fue recibido con mucho entusiasmo por la comunidad migrante, la cual se dispuso a participar activamente en los festejos. Los mismos se caracterizaron, en sus comienzos, como eventos exclusivamente religiosos y

Entrevista a Juan de Dios, Bariloche, 2013.

33 Sacerdote mapuche, muy comprometido con las causas de los sectores más necesitados, encargado de la Parroquia Virgen Misionera.

34 Parroquia ubicada en el barrio Virgen Misionera, barrio carenciado ubicado en la zona sudoeste de la ciudad.

35 Testimonios de Juan de Dios, Andresa y Nilda, Bariloche, diciembre 2010/2013; abril 2011. poco concurridos, donde participaban algunas familias pertenecientes a la agrupación. Estos primeros festejos consistían en realizar, en primer lugar, la novena de preparación espiritual, que la llevaban a cabo en la vivienda Juan de Dios, lugar donde se encontraba residiendo la imagen; y, en segundo lugar, se realizaba la peregrinación, una de las características más significativa de esta advocación. En el caso de Bariloche, como no tenían un santuario o ermita de la imagen hacia dónde dirigirse, optaron por peregrinar hacia la Gruta de la Virgen de las Nieves, una de las advocaciones más populares de la ciudad ubicada a $11 \mathrm{~km}$ del centro, llevando en andas a la imagen de la Virgen de Caacupé. A los pies de la Gruta, luego de unos años, cuando la participación se hizo más importante, organizaron una misa y un almuerzo con comida y bailes populares de Paraguay. Es importante resaltar, que los migrantes deciden no peregrinar con la devoción de la "Inmaculada fundadora" que se desarrolla en el centro, sino que buscan un espacio cercano a sus hogares y a su gente. El desarrollo de esta práctica cultual, también estuvo atravesada por conflictos y tensiones que se manifestaron en diferentes momentos en la agrupación. Uno de los más significativos es el que se produce a fines del año 2009 y principios del 2010, que genera la conformación de una nueva agrupación con más protagonismo de mujeres y jóvenes llamada ANGÜ- ${ }^{36}$ las cuales se apropian de la imagen de la Virgen. Este evento, generó que A.R.P.A trasladara una segunda imagen desde Paraguay de un porte mayor $(80 \mathrm{~cm})$. La misma fue utilizada en los

36 Asociación Nativa Guarani creada en el año 2010 por un grupo de mujeres, liderado por Valentina Han y se declara en disidencia con la dirigencia de A.R.P.A. Durante los primeros años tuvo una importante adhesión de mujeres y jóvenes recién llegados a la ciudad. Actualmente, varias mujeres que habían motorizado la creación de la organización, regresaron a A.R.P.A generando un desmembramiento importante en la asociación. 
festejos del año 2010 profundizando aún más los conflictos entre las agrupaciones. Luego de esta situación de tensión por la posesión de la imagen se le incorpora la disputa por el lugar de residencia de la misma (imagen 3). Durante los años 1993 a 2009, la imagen de la advocación no tuvo un lugar fijo, sino que misionaba en distintos hogares. Para el año 2010, debido a la imposibilidad económica de construir una ermita en el barrio Nahuel $\mathrm{Hue}^{37}$, se la ubicó, provisoriamente, en la casa de Juan de Dios en el km 7 de la Avenida de Los Pioneros en el barrio Virgen Misionera. Para el año 2013 se retoma la búsqueda de un lugar para la imagen y surge la propuesta de trasladar y entronizar la Virgen de Caacupé en la parroquia de Virgen Misionera ubicada en el mismo barrio, consensuada por Juan de Dios y el sacerdote Juvenal Currulef. En los años siguientes, esta entronización, como hemos advertido en trabajos anteriores- ${ }^{38}$, anticipó no sólo un nuevo recorrido de la peregrinación sino también una nueva reconfiguración del espacio religioso desde un anclaje territorial diferente. En función de ello, pudimos identificar dos momentos o etapas por los que transitó el culto: una etapa que dura desde 1994 a 2012 caracterizada por una práctica cultual con una fuerte impronta transnacional ${ }^{39}$, con la apropiación de un

\footnotetext{
Barrio ubicado al sur de la ciudad en donde se encuentra la mayoría de migrantes paraguayos.

38 Ver Barelli 2014, 2015 y 2018

39 Esta perspectiva no la entendemos exclusivamente desde las redes sociales que vinculan el espacio de origen con el de destino, sino también desde la conformación de campos sociales en donde es factible construir espacios de vida multisituados, que involucran tanto a quienes migran como a quienes permanecen en alguno de los puntos del campo migratorio en cuestión. De esta manera, la mirada si bien se complejiza también se enriquece y posibilita una nueva perspectiva de análisis: una perspectiva transnacional, que contempla, según Levitt distintas trayectorias de integración en el país de destino con claras conexiones con el país originario y con otros significados globales.
}

espacio sagrado como es la Gruta de la Virgen de las Nieves; y una segunda etapa, que va desde 2013 a partir de la entronización de la imagen en una parroquia barrial delineando nuevos recorridos y nuevas configuraciones en el desarrollo de la práctica cultual (Barelli, 2018). De esta manera, el traslado de la Inmaculada "migrante" transita un proceso de resignificación donde la "comunidad" paraguaya se reconfigura tanto desde lo ritual como desde lo territorial. Siguiendo a Odgers Ortiz "La devoción al santo patrono no solamente conecta lugares, sino que además, al declinarse en cada nivel escalar de la vida cotidiana, otorga orientaciones prácticas para la construcción del sujeto creyente" (2008: 22). Un "sujeto creyente" que, atravesado por la experiencia de la migración, construye territorialidad en el destino desde una forma "simbólica/expresiva" 40 que le confiere una realidad social que no solo lo vincula y enlaza con su lugar de origen sino que le proporciona un sustento emocional y territorial para transitar el presente y proyectar el futuro. En función de ello, observamos que esta devoción busca diferenciarse de los grupos sociales que se congregan en la capilla de la Inmaculada "fundadora", marcando una territorialidad diferenciada a través de su procesión y peregrinación.

\footnotetext{
Entendidos como un campo de fuerzas y valores religiosos que "eleva al hombre religioso más allá de sí mismo, que lo transporta a un medio distinto de aquel en el que transcurre su existencia" donde la experiencia de lo sagrado se proyecta en el dominio de la emoción y del sentimiento (Rosendhal 1996:30) y en donde la devoción a los santos, como plantea Odgers Ortiz, "permite construir "faros" o anclajes dentro de un territorio fluido, pero no homogéneo, donde la sacralización de espacios determinados hace posible identificar -construir- paisajes específicos, mapas mentales en donde la circulación adquiere un sentido" particular y comunitario (2007: 36).
} 
Figura 4: Imagen de la Virgen de Caacupé entronizada en el atrio de la Parroquia Virgen Misionera de San Carlos de Bariloche. Foto: Inés Barelli,2013.

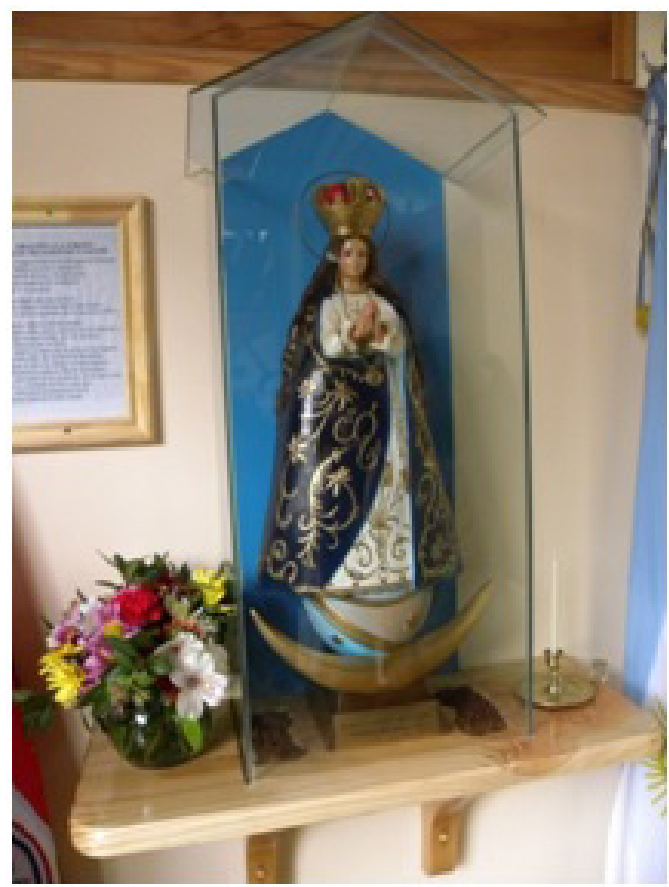

3. Desde la práctica cultual: las procesiones de la Inmaculada "fundadora" y las peregrinaciones de la Inmaculada "migrante" (Caacupé)

La práctica cultual de ambas Inmaculadas contempla la delimitación de territorios sagrados $^{41}$ diferenciales que se construyeron desde dos expresiones espaciales religiosas: la procesión y la peregrinación. La primera

Abordamos la noción de territorio y espacio sagrado desde las propuestas de Rosendahl (2009) y Carballo (2009). En ese sentido entendemos al territorio como aquel espacio que ha sido apropiado por un determinado grupo social para desarrollar necesidades tanto materiales como simbólicas. entendida como un desplazamiento religioso que presenta un circuito pre-establecido, en el que habitualmente las imágenes de devoción se desplazan del lugar sagrado hacia un espacio público junto con sus devotos. Es un cortejo religioso público donde se entonan canciones, se reza y se traslada una imagen sagrada determinada. Este recorrido empieza y termina en el "lugar sagrado" 42 en donde se encuentra entronizada la imagen. Por su parte, las peregrinaciones son procesos rituales que ponen en acción valores y símbolos dominantes de la sociedad. Estas pueden ser entendidas como un ritual de tránsito liminal que conduce a las personas a un estado emocional que les permite introducirse en un espacio tiempo sagrado (Carballo 2009:32). La peregrinación, como acto performativo reiterado, crea y delimita territorio sagrado ya que "extienden su sacralidad informalmente a otros espacios más amplios: la ciudad que los alberga, las adyacencias, las mismas rutas durante la peregrinación, constituyendo un área sacralizada donde las prácticas religiosas (los cánticos, las oraciones individuales o colectivas durante el camino, las promesas, los exvotos y las limosnas en la llegada), se suman y se entretejen al modo de una red cultual que se vuelve más densa con el crecimiento de la devoción" (Fogelman 2013: 11).

Ambas expresiones cultuales, la procesión de la Inmaculada "fundadora", como la peregrinación de la Inmaculada "migrante" en la advocación de Caacupé, no sólo se constituyeron social y simbólicamente de forma diferencial, sino que se configuraron en espacios contrapuestos y en disputa. Es decir, no es lo mismo el centro

42 Concepto que se refiere a todos aquellos segmentos del espacio en donde se distinguen atributos cualitativos a partir y en torno a la divinidad que allí se manifestó. 
turístico de la ciudad, "que mira al lago y que goza de mejores condiciones socioeconómicas anclada en la actividad turística", que la ciudad del alto/marginal, "de espaldas al lago con una población que vive en condiciones desfavorables y en algunos casos de extrema marginalidad" (Matossian 2012: 147-148). En el caso de la Virgen "fundadora" se registra la primera procesión a partir de 1925 cuando cobra importancia con la llegada de la imagen de la Virgen de Lourdes. Esta Inmaculada procesionó en la colonia agrícola-mercantil fuertemente vinculada al comercio con Chile como ya hemos advertido.

El radio de la procesión lo constituyó el ejido urbano de cara al lago, que se estructuró en forma de damero sin tener en cuenta la accidentada toponimia. Su circuito devocional bordeaba el lago principal vía de comunicación e intercambio con el país vecino. La elite barilochense se apropia también de ese acto que marca territorio llevando en andas a la Virgen: "La Procesión recorrió las calles principales del pueblo yendo a porfía las familias más distinguidas en levantar altarcitos a fin de que posándose la Virgen impartiera desde allí su maternal bendición" (ASP CIRevista Vida Misionera 8/12/1930, f. 63).

La escasa asistencia a las misas de la feligresía del poblado, a principios del siglo XX, relegó a la "Fiesta de la Patrona del pueblo" al ámbito del pequeño templo de madera (ASP CI: 8/12/1917).

Figura 5: Procesión del 8 de diciembre de 1919.

Capilla de la Inmaculada Concepción (Bariloche).

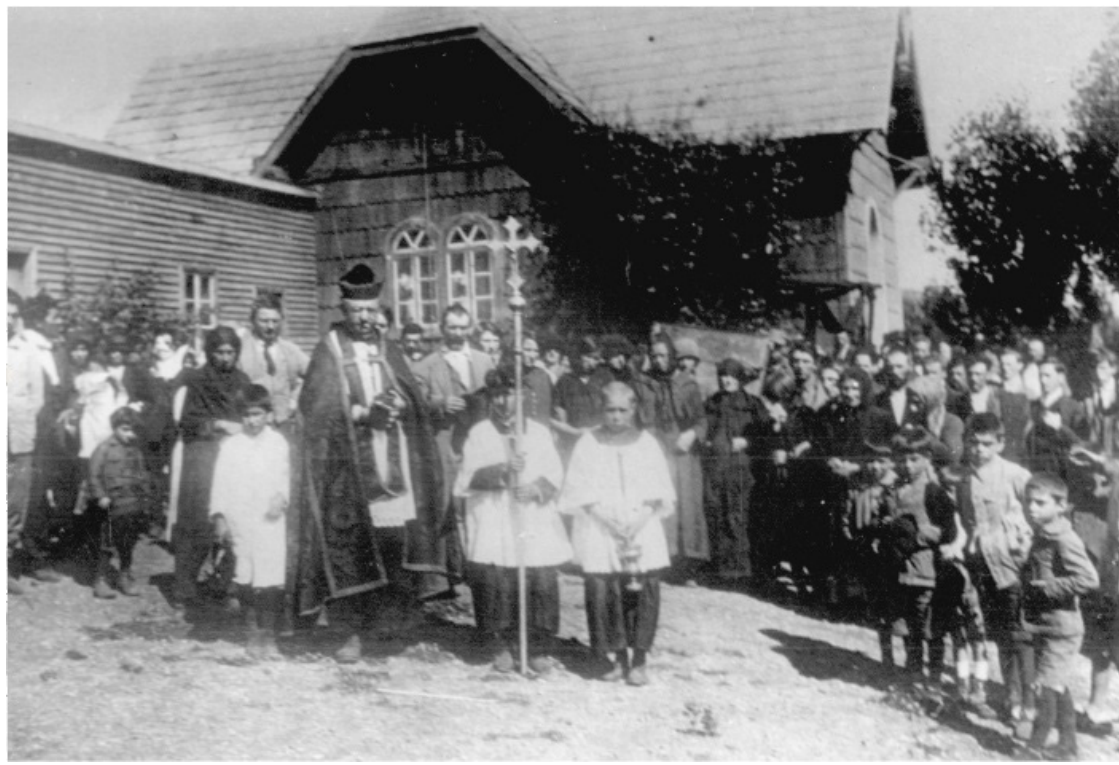

Fuente: API, Carpeta Fotos de Procesiones y Peregrinaciones. 
Recién en 1919 se inició el mes de la Virgen con la novena, las comuniones y una procesión de la "Purísima por la primera vez fue concurrida, aunque el tiempo era un poco feo por el viento, la llevaban ocho señoritas y los caballeros ayudaba a "cambiarse'" (ASP Cl: 8/12/1919). Pero fue en 1925 que la procesión llegó a 300 personas, un número nada desdeñable ante una población estimada en 1250 habitantes hacia 1910, que se mantuvo en 2500 habitantes hacia 1930 (Sánchez et al. 2007:103). Esta procesión fue especialmente significativa por la bendición "de una nueva estatua de la Purísima", que entre sus padrinos y madrinas contaba con los vecinos más distinguidos del pueblo como Primo Capraro, encargado de juntar los fondos mediante una rifa al concluir la procesión (ASP Cl: 8/12/1925).

A partir de ese año, sólo el mal tiempo hizo variar el número de feligreses. La procesión fue incorporando elementos de participación, tales como la "estatua llevada en andas ricamente adornada con flores naturales" (ASP Cl1928:40), la banda demúsica del pueblo (f.40), reemplazada en 1938 por la banda militar, altarcitos al costado del camino (ASP Cl1929 f.58), cofradías (San Luis, Hijas de María, Socias del Apostolado) y las mayordomas que acompañaban a la imagen (ASP Cl8/12/1934:117). La presencia de las "fuerzas del orden", es significativa desde 1940 (ASP Cl: 8/12/1940).

Posteriormente en las décadas siguientes las procesiones modificaron su recorrido por las calles del pequeño poblado de cara al lago. En las crónicas desde 1932 hasta 1940, se advierte un "número extraordinario de fieles que no cupieron en el recinto" (ASP Cl 8/12/1925:.94,1935:137).

Por este motivo en la década del '60 se amplió el territorio sagrado con un nuevo circuito que transitó por las calles más comerciales de Bariloche: O'Connor, Palacios, Mitre, Quaglia

Figura 6: "Procesión de la Inmaculada, en el hermosísimo pueblo andino.

S. Carlos de Bariloche, 8 -XII-1928".

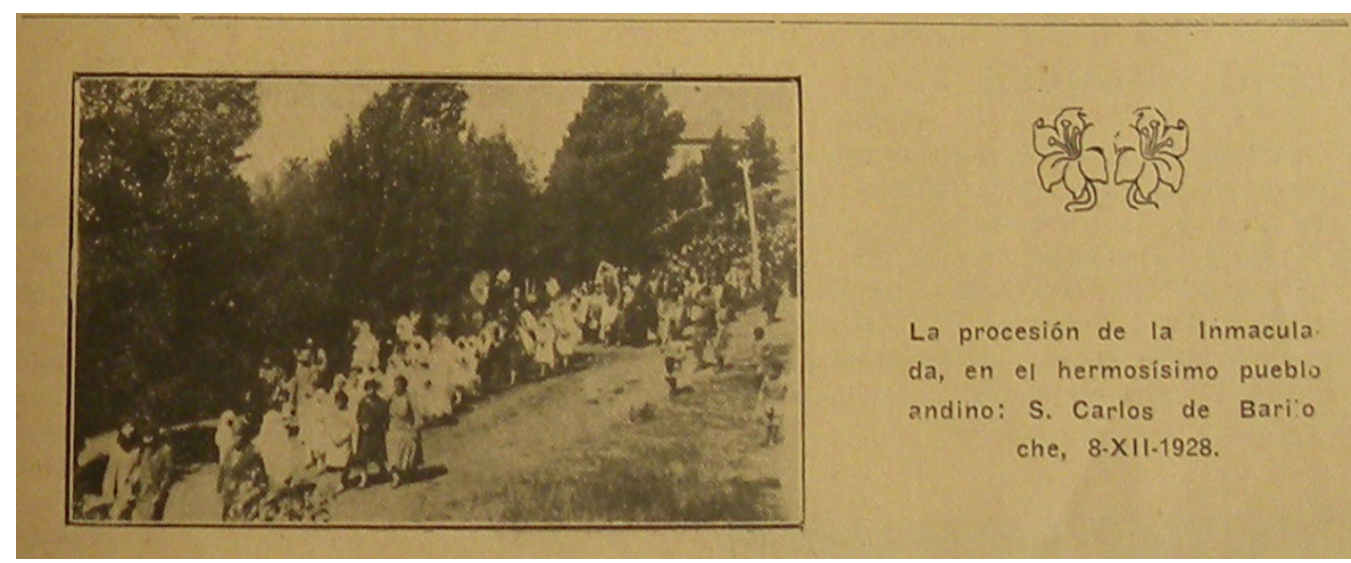

Fuente: APS, Crónicas de la Inmaculada,1928, folio 43. Recorte de la Revista Vida Misionera. 
Figura 7: "S. Carlos de Bariloche. Con motivo de la fiesta de la Inmaculada, se organizaron solemnes cultos. En este número hacemos crónica de los mismos. La procesión; un detalle. APS, Crónicas de la Inmaculada,1930, folio 62. Recorte de la Revista Vida Misionera.

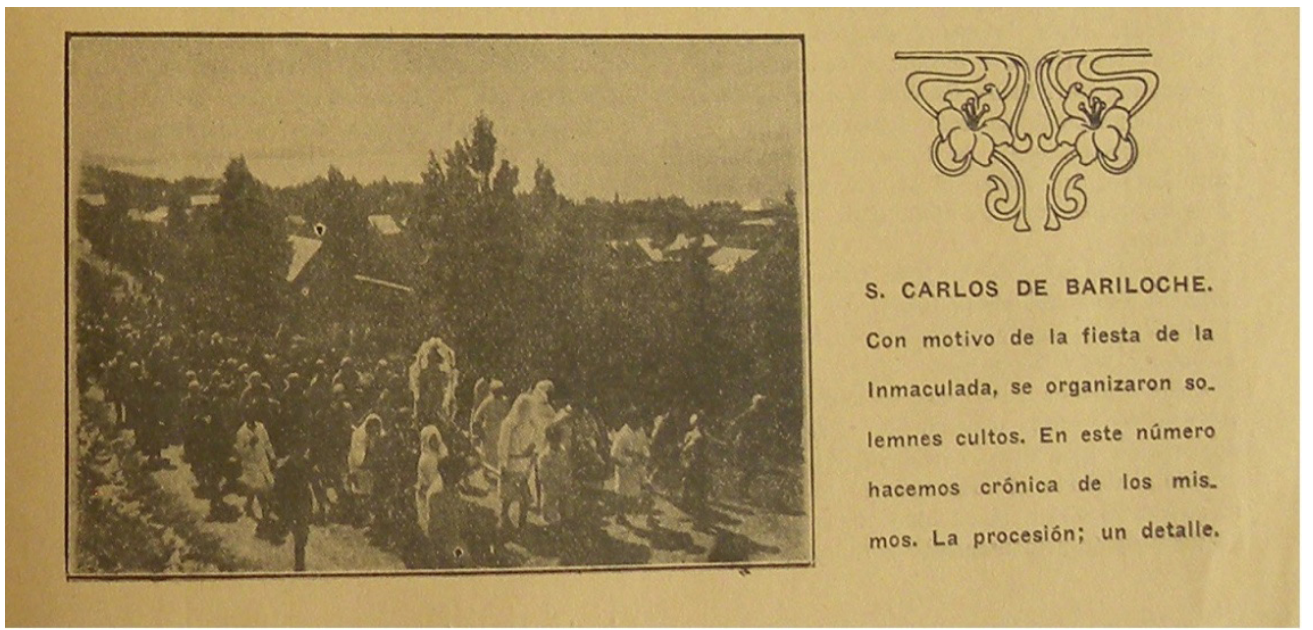

Figura 8: API, Carpeta Procesiones.

Colección Familia Lagos. Procesión de la Inmaculada, 8 de diciembre de 1945

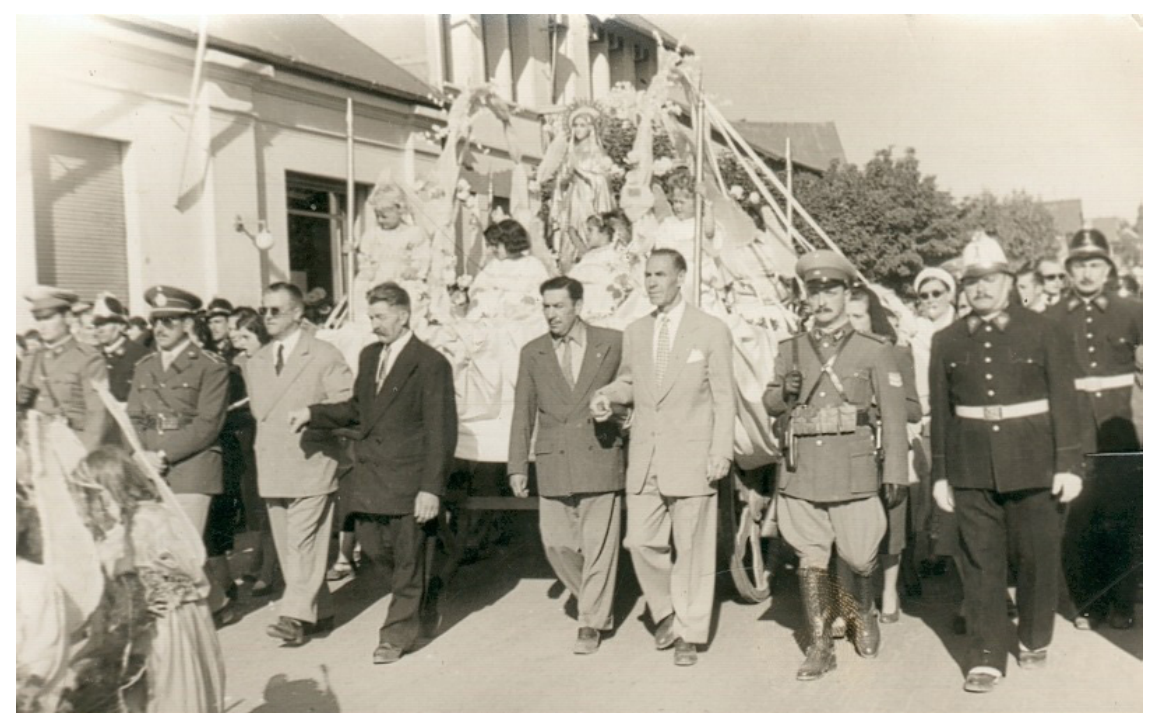


y Moreno, retornando a la calle O'Connor (ASP $\mathrm{Cl}$ 8/12/1967:41). Hacia la década del '70, "se abre la procesión por calle Beschedt" (ASP Cl 8/12/1967:63), y desde 1973 el recorrido elegido se efectuó desde la parroquia ${ }^{43}$, una cuadra más arriba del emplazamiento anterior, y desde allí la procesión transitó por las calles principales de la ciudad (Elflein, Palacios, Gallardo, Quaglia, Mitre), generando una fuerte ligazón con el sector comercial y turístico local. Actualmente esto último se observa en las bendiciones que realiza el párroco de la Inmaculada, quien encabeza la procesión, a los diferentes comercios que adhieren y pegan los carteles de la Virgen al paso de la columna. Las proclamas expresan pedidos específicos por la llegada de turistas y las "buenas temporadas que nos benefician a todos" y el recibimiento de la banda de gendarmería nacional. Es decir, las procesiones, en muchos casos "no se constituyen apenas en rituales religiosos, adquiriendo también un sentido político pudiendo exhibir el orgullo, la solidaridad, la identidad y la fuerza de un determinado grupo social, o su protesta de cara a las condiciones de existencia de procesos sociales en curso" (Rosendhal 2009:51).

Figura 9: Plano de las calles céntricas de Bariloche donde se observan los cambios de recorrido en la procesión del 8 de diciembre (1960,1970 y 1973).

Confección Florencia Galante (IIDyPCa/CONICET/UNRN).

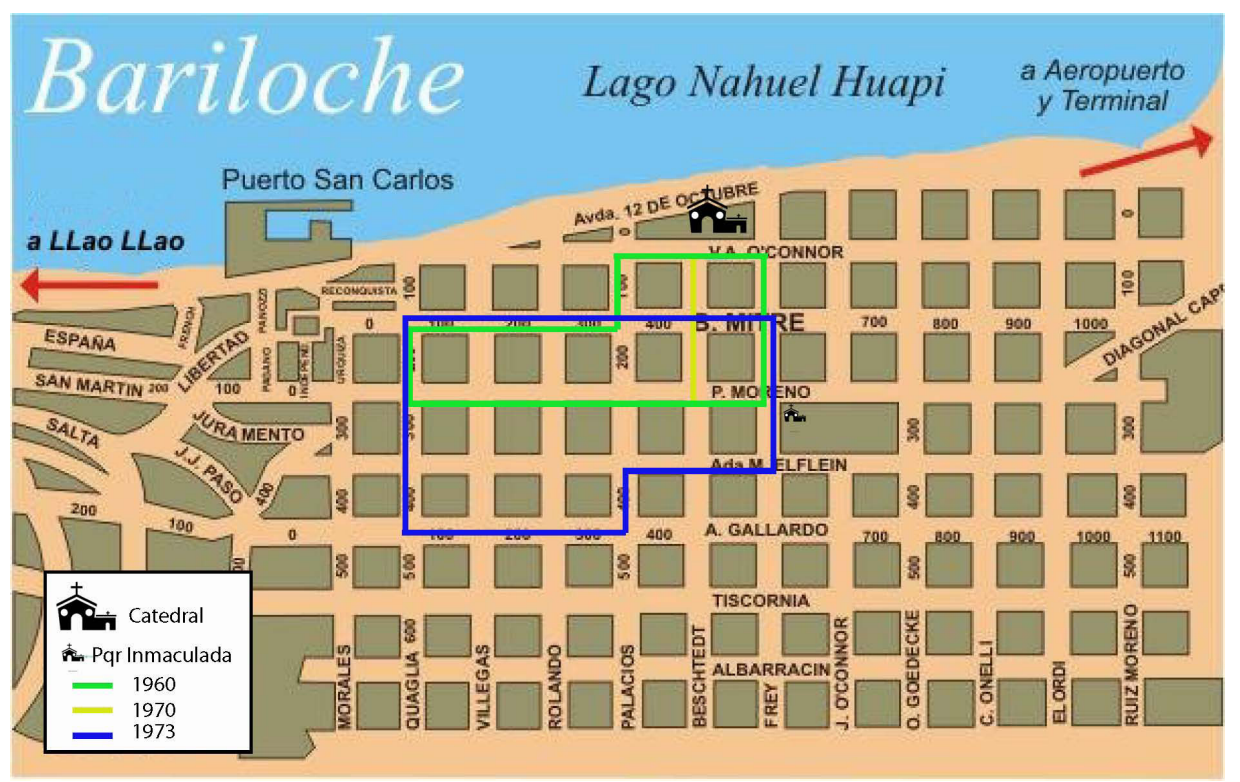

43 "La capilla original no estaba en su actual emplazamiento, sino en la calle Moreno y orientada hacia el lago Nahuel Huapi, a unos 150 metros del ciprés de Moreno. Fue traslada en 1973 mediante rieles tendidos en la ladera hasta su ubicación actual. 
Figura 10: Procesión de la Inmaculada en 1981.

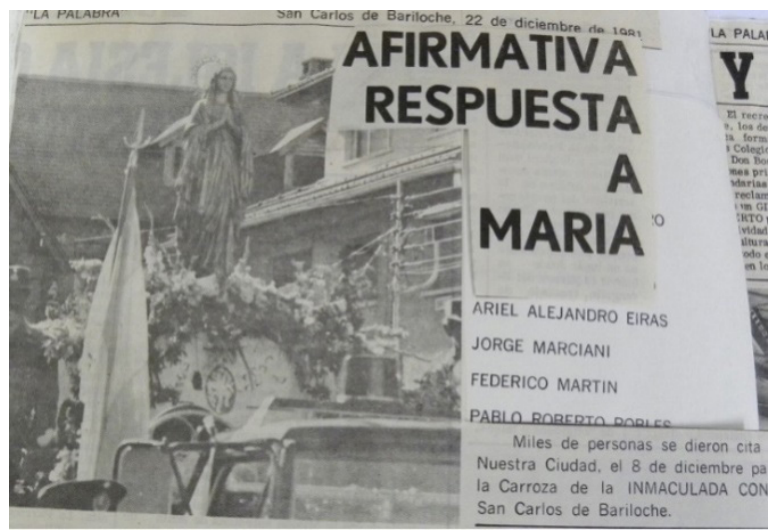

Fuente: ASP, Crónicas de la Inmaculada, 8 de diciembre de 1981, folio. Recorte del Diario La Palabra, 22 de diciembre de 1981.

Figura 11. API. Carpeta de Fotos de Peregrinaciones y Procesiones. Peregrinación de la Inmaculada en San Carlos de Bariloche 1981. Imagen de la Virgen de Lourdes que se veneraba en la Parroquia.

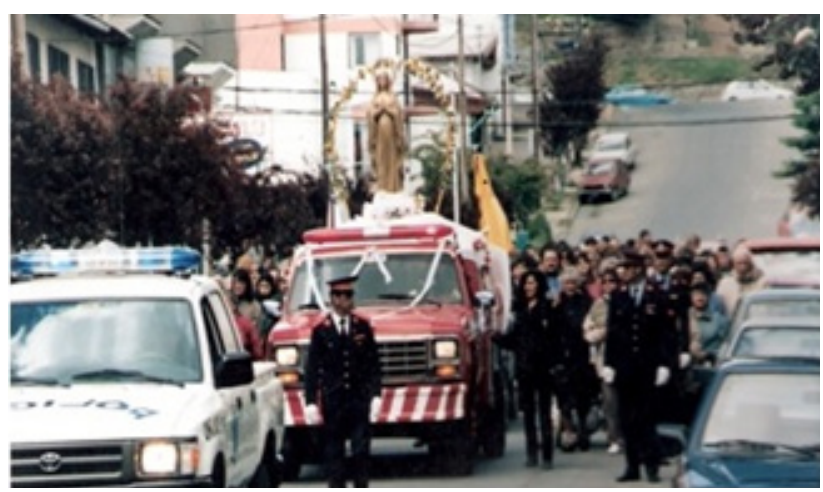

Figura 12: Procesión de la Inmaculada por el centro de Bariloche,2015.

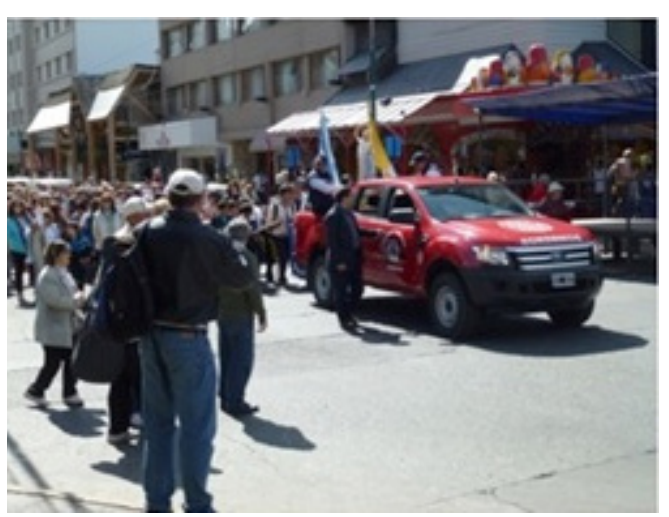

Fuente: Foto Inés Barelli, 2015.

Figura 13: Bendiciones a comercios de las calles céntricas de Bariloche.

Procesión de la Inmaculada 2015.

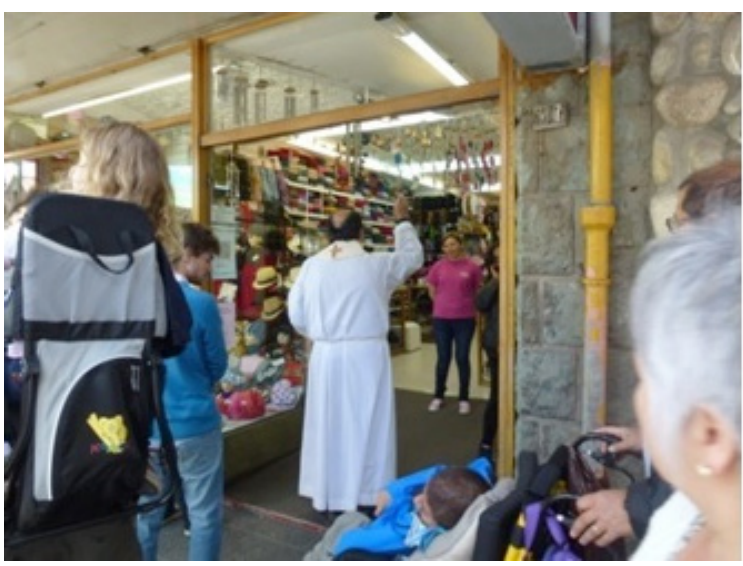

Fuente: Foto Inés Barelli, 2015 
Esta configuración cultual de la Inmaculada "fundadora" se puso en tensión con el traslado en los 90' de la Inmaculada "migrante" bajo la advocación de Caacupé. La práctica cultual de la Inmaculada "migrante" activó no sólo a otro colectivo social, sino que se identificó y sacralizó otro "recorte" espacial de la ciudad: las zonas más pobres y periféricas.

La Virgen de Caacupé, desde los inicios de la práctica cultual, estuvo separada de la Inmaculada "fundadora". Mientras que la Virgen del "centro" procesiona frente al lago, la Inmaculada "migrante" hace su peregrinación hacia la Gruta de la Virgen de la Nieves, espacio alejado del centro y considerado como una zona más próxima a los sectores populares de la ciudad ${ }^{44}$. Esta decisión de peregrinar en la periferia de la ciudad fue una elección por parte de la agrupación. Juan de Dios, el referente de A.R.P.A, en una entrevista nos comentó que la Gruta de la Virgen de las Nieves constituye la devoción que "(...) más convoca gente y más que nada la gente del alto, que es donde están nuestros compatriotas" 45 . Este vínculo de clase operó, con el paso del tiempo, como uno de los pilares de la devoción. Es decir, la práctica cultual fue adquiriendo características propias del lugar de destino que tienen que ver con las situaciones de pobreza y desarraigo que viven los migrantes. En consonancia con esto, resulta significativo mencionar que la devoción a la Virgen de Caacupé logró instalarse en el calendario litúrgico local a expensas de la procesión histórica de la Inmaculada

$44 \quad$ Utilizamos el concepto de "sectores populares" en tanto grupo social en términos de subalternidad con respecto a las élites, de acuerdo al planteo de Hall 1984 y Adamovsky 2012).

45 Juan de Dios, migrante paraguayo y Presidente de ARPA. Bariloche, abril de 2013. "fundadora" que se realiza el mismo día en diferente horario ${ }^{46}$ y recorrido.

En función de estas características, la práctica cultual se fue complejizando. A la peregrinación se le incorpora una celebración religiosa ${ }^{47}$ a los pies de la Gruta y un almuerzo comunitario en donde los migrantes comparten comidas y bailes típicos durante varias horas de la tarde a la vera del río Gutiérrez. En relación a los recorridos sagrados que se configuran en la práctica cultual de la Inmaculada "migrante" podemos señalar dos circuitos en cada una de las etapas en que se desarrolló el culto. Durante la primera etapa (1994-2012) el recorrido de la peregrinación tuvo como punto de salida la plaza Belgrano, ubicada en el centro de la ciudad; como lugar sagrado, la Gruta de la Virgen de las Nieves acompañada de estaciones intermedias de representaciones marianas que se encuentran en el trayecto a la gruta como: la imagen de la Virgen Misionera y la Virgen del Camino. Este recorrido se realizaba a pie con imágenes personales, cantando en guaraní, cebando tereré y enarbolando banderas paraguayas. Así, por ejemplo, lo relataba Juan de Dios:

Vamos cantando, vamos rezando. Por ejemplo, de aquí hasta llegar a Virgen de las Nieves tenemos dos ermitas uno que está en Virgen Misionera y otro en el cruce Virgen del Camino en donde paramos rezamos y así sucesivamente hasta llegar a Virgen de las Nieves. $Y$ el sueño obviamente es... hacer nuestra ermita en un terreno en el barrio Nahuel Hue porque ahí tenemos varios compatriotas viviendo ${ }^{48}$.

46 La procesión de la Inmaculada Fundadora se realiza por la tarde y la peregrinación de la Inmaculada "migrante" de Caacupé se lleva a cabo por la mañana.

47 Desde sus inicios, la misa la presidía Juvenal Currulef, un sacerdote local de la Parroquia Virgen Misionera, cuya historia personal está muy vinculada con los sectores populares de la ciudad.

48 Entrevista a Juan de Dios, Bariloche mayo 2010. 
Para los migrantes devotos, este recorrido es percibido como un momento en donde encontrarse y caminar hablando en guaraní los traslada a lugares añorados, como lo manifestaba un peregrino, es como "estar en casa". Ese sentir que les permite la devoción y el contacto con otros compatriotas, los lleva también a generar redes de contención y ayuda, que se transforman en pilares fundamentales en los que se apoyan los migrantes para afrontar las situaciones de pobreza, vulnerabilidad y desigualdad social por las que habitualmente atraviesa. Así, por ejemplo, lo compartía Nilda, una devota migrante:

Es algo mucho más allá de lo que es simplemente una amistad que no es lo mismo con otra nacionalidad yo sé que si yo agarro algo de ella no hay problema... es usar lo mío como de ella. Encontrarnos en una fiesta es algo muy fuerte, nos ayudamos mucho...no deja de ser un exilio porque no estás en tu tierra colorada con tu gente ${ }^{49}$.

En otras palabras, la práctica cultual, en ocasiones también puede transformarse en "un escenario de disputa política y de reivindicación colectiva hacia ambos lados de la frontera" (Halpern 2009: 217). Es decir, hemos advertido que, durante algunos festejos, la practica devocional, activa un espacio de denuncia social donde los migrantes no sólo pueden manifestar sus reclamos e injusticias por las que atraviesan en su condición de migrantes, sino también hacerse visibles en tanto colectivo social que vive en la ciudad.

Durante la segunda etapa (2013- actualidad), si bien el desarrollo de la práctica continuó con la misma dinámica, observamos un cambio en el circuito espacial por donde circulaba la imagen. Este cambio lo hallamos íntimamente vinculado al proceso de entronización de la imagen en la Parroquia Virgen Misionera en mayo de 2013, ubicada a mitad de camino del recorrido a la Gruta. Durante los primeros años (2013-2016), luego de la entronización, fuimos observando que la estación de la peregrinación en la Parroquia iba adquiriendo otro sentido e importancia en el desarrollo de la peregrinación. Es decir, de ser una parada como todas las otras donde se rezaba y se cantaba paso a ser un momento de encuentro de los fieles con la imagen principal donde se la adoraba y se la incorporaba al frente de la peregrinación para realizar los últimos kilómetros a las Gruta. Esta parada adquirió tanto protagonismo que, para el 2017 se propuso institucionalizarla como el "lugar sagrado" hacia dónde dirigir la peregrinación y desarrollar los festejos marianos. De esta manera, durante el año siguiente, se llevó a cabo un recorte del recorrido devocional ya no centrado en el espacio natural de la Gruta sino en un espacio institucional y barrial, que vuelve a reconfigurar el mapa devocional. El cual, suponemos construirá nuevas articulaciones y acciones de pertenencia, estrechamente vinculadas a un espacio territorial concreto, el barrio Virgen Misionera.

Entrevista a Nilda, Bariloche 14 de abril de 2011 
Figura 14: Peregrinación de la Virgen de Caacupé, 8 de diciembre de 2012. Camino al Cerro Catedral.

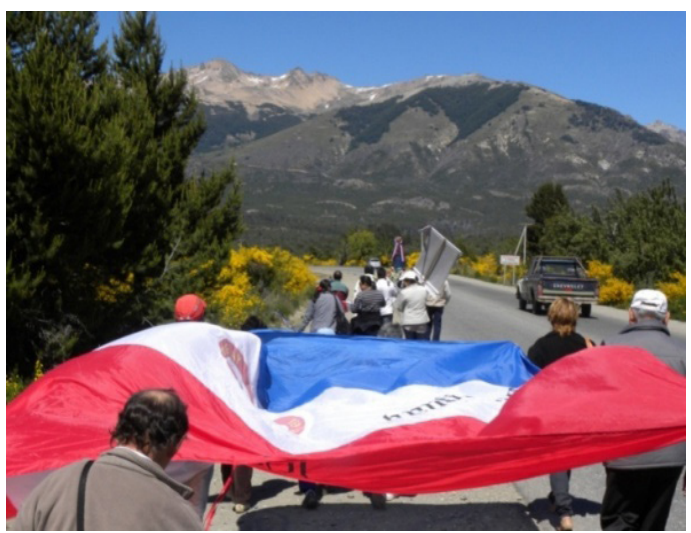

Fuente: Foto Inés Barelli, 2012.

Figura 16: Mapa de lugares sagrados, puntos de referencia y circuito sagrado.

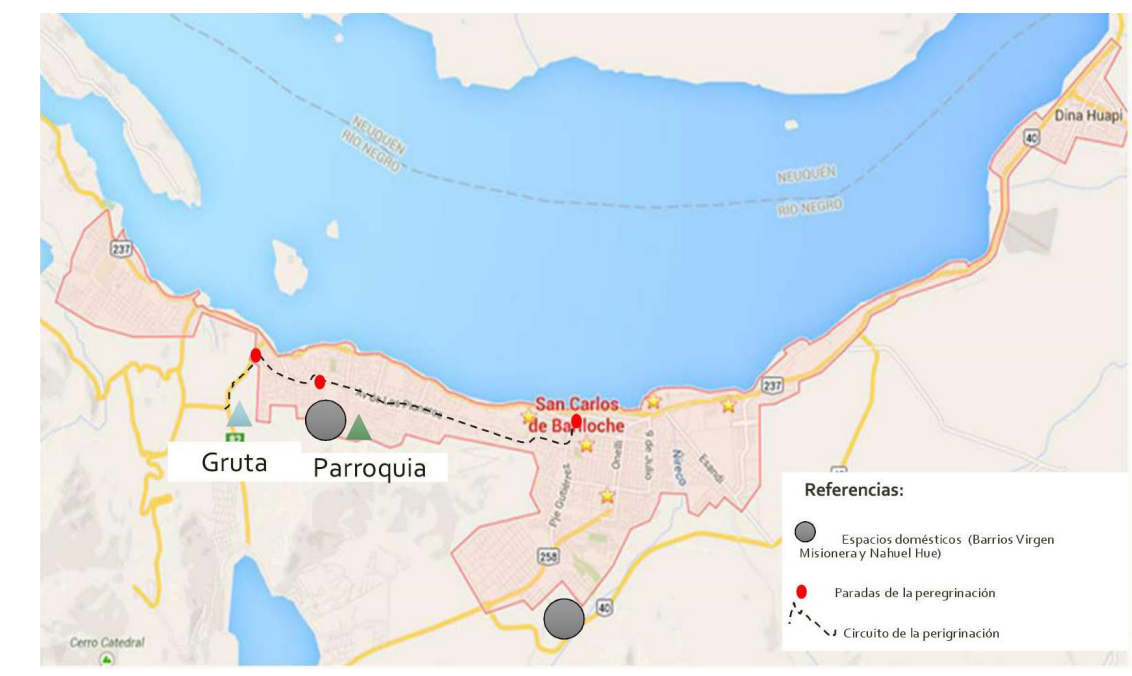

(Fuente: realización de Ana Inés Barelli)
Figura 15: Misa en la peregrinación de la Virgen de Caacupé, 8 de diciembre de 2012. Camino al Cerro Catedral.

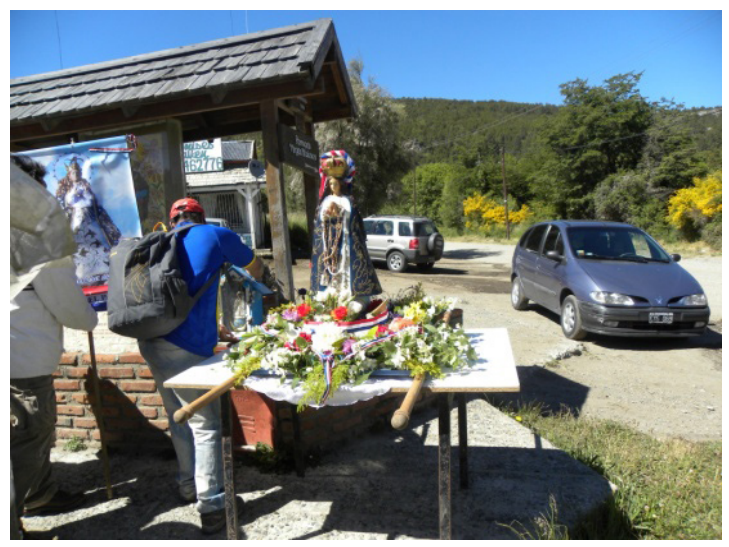

Fuente: Foto Inés Barelli, 2012. 
Figura 17: Imagen de la Virgen de Caacupé entronizada en el atrio de la Parroquia Virgen Misionera de San Carlos de Bariloche.

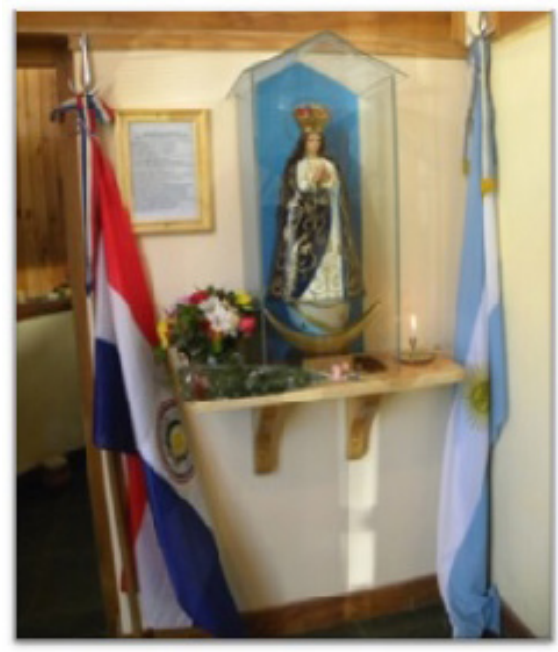

Foto: Inés Barelli,2013.

\section{Conclusiones}

La capilla de la Inmaculada Concepción nació como posta del nodo salesiano de Junín de los Andes para atender desde allí a la población rural y establecer un colegio católico donde ya había educación protestante y se imponía la educación laica y "argentinizadora" del Estado con la ley 1420. La iniciativa partió de los "vecinos caracterizados" del poblado, que se constituyeron en la "aristocracia local" de poder económico y vínculos políticos suficientes como para llevar a buen puerto esta iniciativa. En este caso, la comisión pro templo estuvo formada por miembros de la empresa Chile -Argentina y autoridades del pueblo y el Territorio. La alianza entre la élite local y la Iglesia se materializó en la capilla y la presencia definitiva de la Congregación salesiana desde
1915, constituyéndose en nodo misionero con parroquia, oratorio, escuela y hospital. La segunda materialización de la alianza de la élite y la Iglesia, la constituyó la elección del patronazgo de la capilla: La Virgen Auxiliadora en el momento de la colocación y bendición de la piedra fundamental y la Inmaculada, tras la inauguración oficial y bendición del Templo.

Esta secuencia nos permitió tomar a las advocaciones marianas como dispositivos que construyen territorialidad devocional en clave identitaria para resignificar espacios reales y simbólicos y como construcciones territoriales dinámicas de inclusión o exclusión. En estos territorios devocionales y de acuerdo a cada contexto histórico cada advocación marca fronteras simbólicas a partir de iconos y rituales que localmente se resignifican. La elección de una u otra devoción mariana hace referencia a lo que Brown llama proceso de "comunalización" en el que cada grupo se percibe como propio construido a partir de sus relaciones sociales, culturales e históricas. Por ello, mientras para los Salesianos la Virgen Auxiliadora es su símbolo por excelencia, para las comisiones de Damas y Caballeros Pro Templo que conformaban la élite local, la Inmaculada resulta el ícono adecuado para el desarrollo del catolicismo orgánico que se afirma en la etapa de los hermanos Bustillos en Bariloche. Su procesión marcó desde 1925 la territorialidad sagrada de la feligresía local más tradicional por las calles del centro, identificándose con la "Suiza Argentina" de cara al Lago.

Este mismo proceso identitario y territorial se observa en otra Inmaculada bajo la advocación de Nuestra Señora de los Milagros de Caacupé que en los años 1990 que se resignificó en la ciudad con el traslado de su imagen por un 
dirigente de la comunidad paraguaya. Esta Inmaculada "migrante", se constituyó en una devoción de adscripción nacional con un fuerte contenido social que se instaló en los sectores más pobres y desdeese lugar interpeló al espacio local. Las disputas entre las colectividades paraguayas ARPA y ANGÜ-A, se trasladaron hacia la posesión de la imagen y el sitio destinado para su veneración, la que se resolvió con su entronización, en la parroquia "Virgen Misionera", liderada por un cura mapuche y tercermundista ${ }^{50}$. Su circuito territorial marcó una fuerte impronta transnacional: entre 1994 y 2012 con la participación del colectivo paraguayo ARPA y la imagen en la Gruta de la Virgen de las Nieves, patrona de la diócesis de Bariloche; y en el 2013 con la entronización de la imagen en "Virgen Misionera". Fue esta disputa entre las agrupaciones la que determinó las distintas imágenes de esta "Inmaculada Migrante" delineando nuevos recorridos y nuevas configuraciones en el desarrollo de la práctica cultual.

\section{Bibliografía}

\subsection{Fuentes}

\subsubsection{Fuentes escritas}

Archivo Histórico de las Misiones Salesianas de la Patagonia (AHMSP). Crónicas de la Parroquia "Inmaculada Concepción" (CPIC) (1907-1957/1957-63/ 1966-1973).

\subsubsection{Fuentes orales}

\section{Entrevistas}

Juan de Dios, Presidente de la Agrupación de Residentes Paraguayos (A RPA). Bariloche 2013.

\subsection{Bibliografía}

Adamovsky, E. 2012. Historia de las clases populares en la Argentina. Desde 1880 hasta 2003. Buenos Aires: Sudamericana.

Ameigeiras, A. 2014. "Catolicismo e identidad nacional en la Argentina. La construcción de la nación y el simbolismo mariano" en Simbolos y rituales religiosos e identidades nacionales. Colección Grupo de Trabajo CLACSO. Buenos Aires.

Barelli, A. 2014."'Encontrarnos por la Virgencita es una fiesta!". La Virgen de Caacupé como dispositivo de "paraguayidad" en San Carlos de Bariloche, Argentina (1970-2012). Latinoamérica. Revista de Estudios Latinoamericanos. Coyoacán: CIALC. UNAM. 2014 vol. n58. p205 - 236. issn 1665-8574.
Barelli, A. 2015. "Estrategias de visibilización: los migrantes paraguayos y la devoción a la Virgen de Caacupé en San Carlos de Bariloche (1970-2013)". En Barelli Ana Inés y Patricia Dreidemie (comp) Migraciones en Patagonia. Subjetividades, diversidad y territorialización. Viedma: Universidad Nacional de Rio Negro.2015. p179 -204. isbn 978-987-3667-19-0

Barelli, A. 2018. "Dinámicas de resignificación cultual y nuevas territorialidades en torno a la Virgen de Caacupé de los migrantes paraguayos en Bariloche, Argentina (1993-2016)". Confluenze Revista di studiiberamericani. Bologna: Dipartimento di Lingue, Letterature e Culture Moderne, Università di Bologna. 2018 vol. $n^{\circ}$. p - . issn 2036-0967.

Barelli, A. 2013. Las devociones marianas de los migrantes latinoamericanos en San Carlos de Bariloche (1970-2012). Prácticas religiosas y procesos identitarios. Tesis Doctoral Bahía Blanca:Universidad Nacional del Sur.

Brow, J. 1990. "Notes on Community, Hegemony and Uses of the Past". AnthropologicalQuartely, (I) 63: 1-6.

Carballo, C. (coord). 2009. Cultura, territorios y prácticas religiosas. Buenos Aires: Prometeo.

Dimitriu, A.M. 2001. "Magallanes en bermudas. Turismo, organización espacial y crisis". Nueva Sociedad 171: 43-57.

Enrich, F. 1891. Historia de la Compañía de Jesús en Chile. Barcelona: Rosales.

Esquerda Bifet, J. 1998. Diccionario de la Evangelización. LABAC, Madrid. Roma.

Farioli, Paola (2002) La Virgen de Don Bosco. ELLEDICI,

Fogelman, P. 2006. "El culto mariano y las representaciones de lo femenino. Recorrido historiográfico y nuevas perspectivas de análisis". La Aljaba. Revista de Estudios de la Mujer, vol. X, Universidad Nacional de Lujan/ Universidad Nacional de la 
Pampa/ Universidad Nacional del Comahue, Luján.

Fogelman, P. 2013. Introducción del libro: Fogelman, P, Ceva, M y Touris, C (Ed). 2013. El culto mariano en Luján y San Nicolás. Religiosidad e historia regional. Buenos Aires: Biblos.

Fonk, F. 1900. "Viajes de Fray Francisco Menéndez". Diario para descubrir la Laguna de Nahuel Huapi (1791-92) Menéndez, F. Valparaíso: Niemeyer.

Giorgis, Marta (2004) La Virgen prestamista. La fiesta de Urkupiña en el boliviano Gran Córdoba. Centro de Antropología Social, Antropofagia, Buenos Aires.

Hall, Stuart (1984) "Notas sobre la deconstrucción de lo "popular"” en: Samuel, Ralph (ed), Historia popular y teoría socialista. Crítica. Barcelona.

Halpern, G. 2009. Etnicidad, inmigración y política. Representaciones y cultura política de exiliados paraguayos en Argentina. Buenos Aires: Prometeo.

Julià. D.1974. "La religión". Hacer la Historia. Le Goff, J y Norà,P (dir.).Barcelona:Laia. V. II. 137-167

López Santos, Luis (1969) Hagiotoponimiay la vida religiosa. Consejo Superior de Investigaciones Científicas. Madrid.

Mallimaci, Fortunato. 1992. "El Catolicismo argentino desde el liberalismo integral a la hegemonía militar". 500 años de cristianismo en Argentina, AAVV. Buenos Aires CEHILA - Centro Nueva Tierra.

Martín, Eloísa (1997) "La Virgen de Luján: el milagro de una identidad nacionalcatólica". VII Jornadas sobre Alternativas Religiosas en Latinoamérica 27 al 29 de noviembre, Buenos Aires.

Matossian, B. (2012). Migración y segregación urbana en ciudades medias. Chilenos enSan Carlos de Bariloche, PatagoniaArgentina. Berlín: Editorial Académica Española.

Méndez, L. 2007 "Circuitos económicos en el gran lago. La región del Nahuel Huapi entre 1880 y 1930". Hecho en Patagonia: La historia en perspectiva regional, Bandieri, S; Blanco, G y Varela, G (Eds.). Neuquén: EDUCO. 231-248.

Méndez, L. y Muñoz Sougarret, J. 2013. "Economías cordilleranas e intereses nacionales. Genealogía de una relación. El Caso de la compañía comercial y ganadera Chile Argentina (1895-1920)". Fronteras en movimiento e imaginarios geográficos. La cordillera de los Andes como espacialidad socio cultural, Núñez, A, Sánchez, R y Arenas, F. Santiago. (Eds.). Santiago: RIL.169-175.

Mora Rivera, G y Odone Correa, C. 2011. "Niño Jesús en Cusco colonial y Azápa contemporáneo. Un ejercicio de análisis de bultos como soportes"

Navarro Floria, P y Vejsbjerg, L. 2009. "El proyecto turístico barilochense antes de Bustillo: entre la prehistoria del Parque Nacional Nahuel Huapi y el desarrollo local". Estudios y Perspectivas en Turismo 18 (4): 414-433.

Nicoletti, M. y Barelli, A. 2014. "Devociones marianas en la ciudad de San Carlos de Bariloche (Argentina): construcciones identitarias sociales y marcas territoriales". Revista Brasileira de História das Religiões. Maringá: Universidade Estadual de Maringá, Brasil. 2014 vol.7 n¹9. p5 - 30. issn 1983-2850.
Nicoletti, M. y Barelli, A.2015. "Devotos, ofrendas y promesas en el espacio religioso de la Virgen de las Nieves en San Carlos de Bariloche, Argentina. Ciencias Sociales y Religión. Porto Alegre: Ciencias Sociales y Religión/ CiênciasSociais e Religião. 2015 vol. 17 n 23. P.138 - 161. Issn 1518-4463.

Nicoletti, M. y Barelli, A. 2012. Entre la realeza y la popularidad: la Virgen Auxiliadora, patrona dela Patagonía y la Virgen Misionera, patrona de la provincia de Río Negro. Sociedad y Religión.Buenos Aires: Centro de Estudios e Investigaciones Laborales (CONICET). 2012 vol.XXI n³8. P. 109 - 141

Nicoletti, M. 2014. "Pasado y presente: los jesuitas de la misión Nahuel Huapi (1670-1674 y 1704-1717) y la devoción Mariana". Antiguos jesuitas en Iberomérica, (2) 1: 41-64.

Odgers Ortiz, O. 2007. "Santos nómadas cosmopolitas: los nuevos espacios circulatorios de los santos patronos locales", en Iztapalapa, vol. 28, núms. 62-63, pp. 29-38.

Odgers Ortiz, Olga. 2008. "Construcción del espacio y religión en la experiencia de la movilidad. Los Santos Patronos como vínculos espaciales en la migración México/Estados Unidos". Migraciones Internacionales, vol. 4, núm. 3, enero-junio, 2008, pp. 5-26. El Colegio de la Frontera Norte, A.C.Tijuana, México

Reingold, P.V. 2000. Nuestra Señora de los Milagros de Caacupé. Buenos Aires: Santa María.

Rosendahl, Z. 1996. Espacio y Religión: un abordaje geográfico. Rio de Janeiro: UERJ, NEPEC.

Rosendahl, Z. 2009. "Hierópolis y procesiones: lo sagrado y el espacio". Cultura, territorios y prácticas religiosas Carballo, C. (coord.). Buenos Aires: Prometeo. 43-56.

Ruffini, M. 2017. La Patagonia mirada desde arriba. El grupo Braun-Menéndez Behety y la Revista Argentina Austral, 19291967. Rosario, Prohistoria.

Sánchez, D Sassone, S y Matossian, B. 2007. "Barrios y áreas sociales de San Carlos de Bariloche: análisis geográfico de una ciudad fragmentada" Bitácora Urbano Territorial (27) 2 :101-108.

Sassone, S. y Hughes, J. 2009. "Fe, devoción y espacio público: cuando los migrantes construyen lugares", Carballo, Cristina (ed). Cultura, territorios y prácticas religiosas. Prometeo. Buenos Aires. 151-172.

Schenone, H. 2008. Santa María. Buenos Aires: Universidad Católica Argentina.

Stella, P. 1981. Don Bosco nellastoriadellareligiositácattolica. Vita e opere. Vol.I. Roma: LAS.

Temporelli, C. 2008. María, mujer de Dios y de los pobres. Relectura de los dogmas marianos. Buenos Aires: San Pablo.

Teobaldo, M; García, A.B y Hernández, A. 1997. La educación en las provincias [1945-1985]. Buenos Aires:Galerna. 253-313

Teobaldo, M. y Nicoletti, M. 2007. "La Educación en el Territorio de Río Negro". Horizontes en Perspectiva: contribuciones para la Historia de Río Negro, 1884-1955, Ruffini, M y Masera, R (coord). vol.1. Viedma: Legislatura de Río Negro y Fundación Ameghino.271-306.

Wright, Pablo (2009) Antropología de la religión: sobre santos, vírgenes y las dimensiones de lo sagrado. Buenos Aires (s/p). 
